\title{
Statistical study to identify the key factors governing ground water recharge in the watersheds of the arid Central Asia
}

\author{
Binq-Qi Zhu • Yue-Ling Wang
}

Received: 27 October 2014 / Accepted: 17 December 2015 /Published online: 30 December 2015

(C) Springer International Publishing Switzerland 2015

\begin{abstract}
Understanding the source and recharge of ground waters is of great significance to our knowledge in hydrological cycles in arid environments over the world. Northern Xinjiang in northwestern China is a significant repository of information relating to the hydrological evolution and climatic changes in central Asia. In this study, two multivariate statistical techniques, hierarchical cluster analysis (HCA) and principal component analysis (PCA), were used to assess the ground water recharge and its governing factors, with the principal idea of exploring the above techniques to utilize all available hydrogeochemical variables in the quality assessment, which are not considered in the conventional techniques like Stiff and Piper diagrams. Q-mode HCA and R-mode PCA were combined to partition the water samples into seven major water clusters $(\mathrm{C} 1-\mathrm{C} 7)$ and three principal components $(\mathrm{PC} 1-$ PC3, PC1 salinity, PC2 hydroclimate, PC3 contaminant). The water samples $\mathrm{C} 1+\mathrm{C} 4$ were classified as recharge area waters $\left(\mathrm{Ca}-\mathrm{HCO}_{3}\right.$ water $), \mathrm{C} 2+\mathrm{C} 3$ as
\end{abstract}

Electronic supplementary material The online version of this article (doi:10.1007/s10661-015-5075-4) contains supplementary material, which is available to authorized users.

B.-Q. Zhu $(\bowtie) \cdot$ Y.-L. Wang

Key Laboratory of Water Cycle and Related Land Surface Processes, Institute of Geographic Sciences and Natural Resources Research, Chinese Academy of Sciences, Datun Road, No. A11, Chaoyang District, Beijing 100101, China

e-mail: zhubingqi@igsnrr.ac.cn transitional zone waters $\left(\mathrm{Ca}-\mathrm{Mg}-\mathrm{HCO}_{3}-\mathrm{SO}_{4}\right.$ water), and $\mathrm{C} 5+\mathrm{C} 6+\mathrm{C} 7$ as discharge area waters $\left(\mathrm{Na}-\mathrm{SO}_{4}\right.$ water). Based on the Q-mode PCA scores, three groups of geochemical processes influencing recharge regimes were identified: geogenic (i.e., caused by natural geochemical processes), geomorphoclimatic (caused by topography and climate), and anthropogenic (caused by ground water contamination). It is proposed that differences in recharge mechanism and ground water evolution, and possible bedrock composition difference, are responsible for the chemical genesis of these waters. These will continue to influence the geochemistry of the northern Xinjiang drainage system for a long time due to its steady tectonics and arid climate. This study proved that the chemistry differentiation of ground water can effectively support the identification of ground water recharge and evolution patterns.

Keywords Hydrogeochemistry · Hierarchical cluster analysis · Principal components analysis · Ground water recharge $\cdot$ Northern Xinjiang $\cdot$ Central Asia

\section{Introduction}

The lithosphere, oceans, and the atmosphere form the largest reservoirs on the earth. The main link between these reservoirs is the hydrological cycle, which provides fresh water for humans and continental ecosystem functions. At present, the world is experiencing an undeniable temperature increase and thereby inevitably is faced with various environmental problems, among 
which the acceleration of global water cycle processes induced by increasing temperature is prominent (Menzel and Burger 2002). The consequences of these hydrological changes for future water availability, predicted with high confidence and already diagnosed in some regions, are likely to be severe (Barnett et al. 2005), especially in the arid zones.

In central Asia, high mountains, particularly the Tibetan Plateau and Tianshan Ranges, function as barriers for atmospheric circulation and keep moisture from reaching an extensive region in western China, causing arid and hyperarid climatic conditions (Domros and Peng 1988; Sun et al. 2010). These regions receive low and variable annual rainfall $(<500 \mathrm{~mm} /$ year in winter seasons and $<200 \mathrm{~mm} /$ year in summer seasons) and are characterized by potential evapotranspiration that is far greater than the precipitation (ratio of annual mean precipitation (AMP) to mean potential evapotranspiration <0.5; UNEP 1992). Natural water resources in these regions are generally scarce and highly uncertain. Fresh water is definitely a limited and indispensable resource upon which humans and ecosystems depend. The water availability is greatly influenced by the local geology and climate (Zhu et al. 2012a). Understanding of the source and recharge of natural waters is of great significance not only to the policy makers for regional planning but also to the scientists interested in hydrological cycles in arid environments over the world (Meyer et al. 1988; George et al. 1997; Arnell 1999; Kimbadi et al. 1999; Cramer and Hobbs 2002; Hagg et al. 2007; Jolly et al. 2008; Zhu et al. 2012b; Dragon and Gorski 2015).

Northern Xinjiang in northwestern China is the geographical center of the Asian Continent, which can be regarded as a significant repository relating to the hydrological evolution and climatic changes in central Asia. At present, with the increased demand for natural water resulting from fast demographic growth, accelerated urbanization, and economic and agricultural activity diversification, natural water resources in this arid region are relatively low, compared to the demand. Water resource becomes overexploited in some places as its natural recharge by rainwater does not succeed in maintaining the hydrologic balance. The imbalance between the water demand and resources induces the degradation of the water quality. In such a case, the water recharge sources are a key to understand the hydrodynamic and physicochemical conditions of the natural water. Until now, however, little work focusing on these questions has been done in this arid drainage system.

Under arid conditions, tracer methods offer a valuable support for traditional natural water studies. As rivers carry the imprints of chemical erosion on the continental and local scale in the forms of dissolved materials, geochemical methods have been applied widely to examine the spatial variability in the water's characteristics and to better understand the functioning of hydrosystems (e.g., Pilla et al. 2006; Zhu and Yang 2007; Stadler et al. 2010; Zhu et al. 2011), as they are basically an independent method from hydraulics of filter flow and, therefore, enable to complement hydraulic methods on evaluating natural water recharge or mixing of waters from different origins. The objectives of this study were (1) to examine the processes controlling the geochemical genesis of ground waters in northern Xinjiang drainage system and (2) to identify the factors potentially governing the recharge and evolution of these waters, by using two well-known multivariate statistical methods. Given the relatively complex geographical and geological settings of the study area, the authors hope that the multivariate statistical techniques could help distinguish the role of natural and nonnatural contexts in this examination, since the application of multivariate statistical techniques has been proved to be a robust tool for the characterization of hydrological systems, compared with the limitations of traditional graphical techniques (Guler et al. 2002).

\section{Regional setting}

The study area is the northern part of the Xinjiang Province in northwestern China that extends between longitudes $78-90^{\circ} \mathrm{E}$ and latitudes $42-50^{\circ} \mathrm{N}$ (Fig. 1a), covering an area of approximately $603,000 \mathrm{~km}^{2}$. Northern Xinjiang is an important part of the Central Asia Orogenic Belt (CAOB) and the Central Asia Metallogenic Province (CAMP) (Fig. 1b) (Jahn et al. 2000; Zhu et al. 2013a). The region is bounded by the Tianshan Mountains to the south and the Altai Mountains to the north. The topography is generally flat in the central plain and is rather cragged in the peripheral mountainous areas, with elevations from less than $500 \mathrm{~m}$ above sea level (asl) in the center of the Zhungarer Basin to more than $3000 \mathrm{~m}$ asl in the south and north (Fig. 1c). The wide piedmonts and pediment 

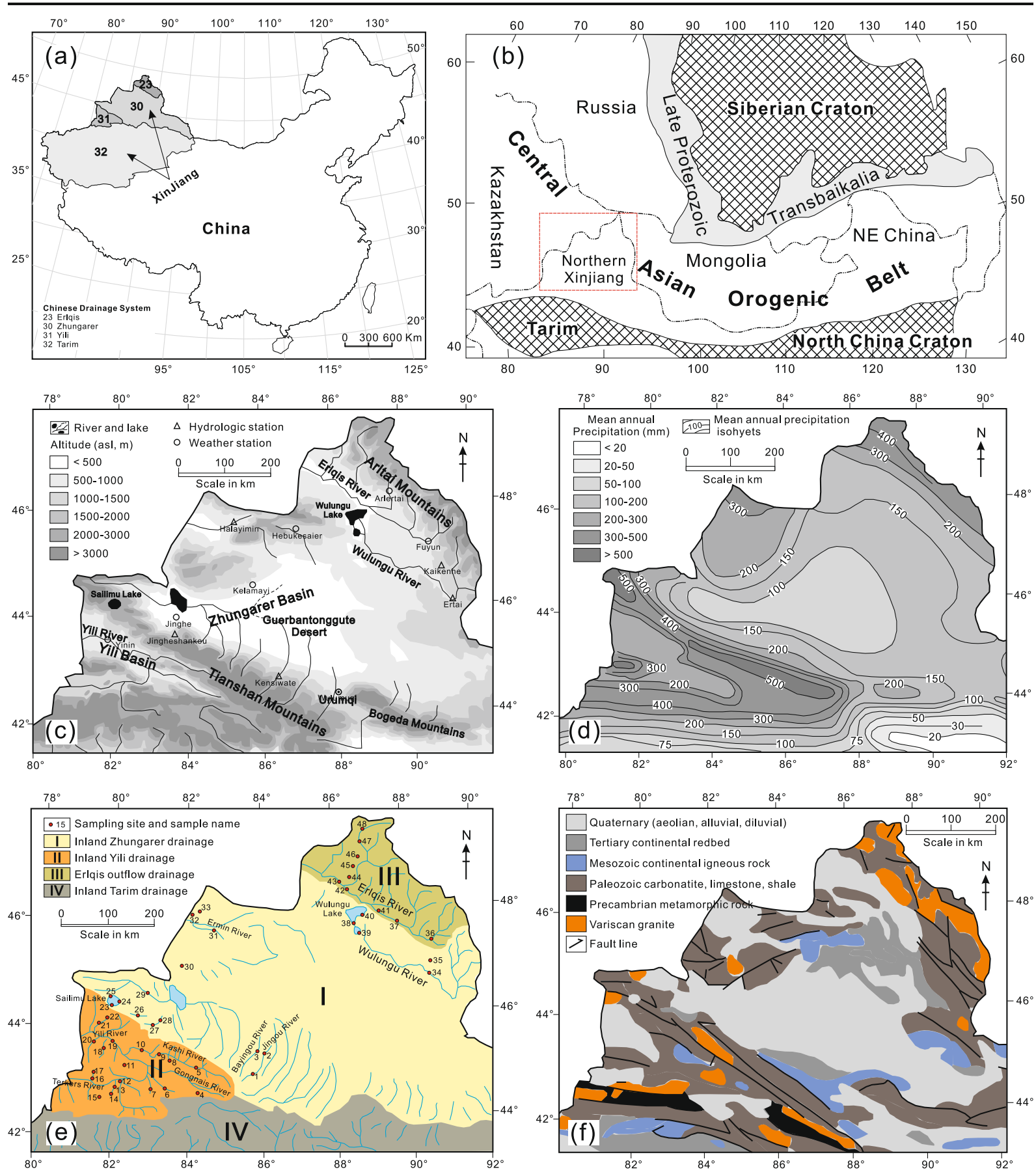

Fig. 1 The location of the study area in the Central Asia. a Four drainage watersheds in Xinjiang, northwestern China, $\mathbf{b}$ the location of northern Xinjiang in the Central Asian Orogenic Belt (after Jahn et al.

(2000)), c topographical map, $\mathbf{d}$ annual mean precipitation (AMP) isohyets distribution map, e hydrological setting and sampling locations map, and $\mathbf{f}$ lithological distribution map of the northern Xinjiang

plains are marked by the Gobi desert, grassland for herding and oasis areas with intensive agricultural activities.

The area is characterized by an arid climate with cold winter and hot summer with mean annual temperature about $5{ }^{\circ} \mathrm{C}$, ranging from -10 to $-20{ }^{\circ} \mathrm{C}$ in winter 
seasons and from 28 to $33{ }^{\circ} \mathrm{C}$ in summer seasons. The long-term average rainfall ranges from 60 to $150 \mathrm{~mm}$ in the central plain and from 200 to $500 \mathrm{~mm}$ in the surrounding mountainous areas (Fig. 1d). The potential evapotranspiration is approximately $1000-3500 \mathrm{~mm} /$ year. Other sources of water for evapotranspiration processes are the surface water system in the study area which includes the rivers, canals, and drains as well as many ponds.

The northern Xinjiang includes three watersheds: the Zhungarer, the Yili, and the Erlqis (Fig. 1e). The Zhungarer and Yili watersheds are inland continental watersheds and the Erlqis watershed drains into the Arctic Ocean. Water resources in northern Xinjiang are mainly distributed in Yili $\left(170.9 \times 10^{8} \mathrm{~m}^{3}\right)$, Altai $\left(129 \times 10^{8} \mathrm{~m}^{3}\right)$, and Tacheng districts $\left(61.6 \times 10^{8} \mathrm{~m}^{3}\right)$, and the total volume of the surface water in northern Xinjiang is about $435.7 \times 10^{8} \mathrm{~m}^{3}$. The temporal distribution of runoff in a year is extremely heterogeneous with $50-70 \%$ in summer, $10-20 \%$ in both spring and autumn, and less than $10 \%$ in winter. The uneven spatial-temporal distribution of water resources and dry climate environment determine the complete dependence of oasis agricultural activities on irrigating system. The Zhungarer Basin $\left(379,000 \mathrm{~km}^{2}\right)$ is located in the central part of northern Xinjiang and is the geographic center of the Asian Continent. The basin is a structural depression filled with unconsolidated Quaternary and Tertiary sediments as much as 500$1000 \mathrm{~m}$ in thickness (XETCAS 1978) and is an extension of the Paleozoic Kazakhstan block surrounded by Paleozoic folded mountains. Aeolian deposits are widespread in this basin. The Gulbantonggute Sand Sea $\left(48,800 \mathrm{~km}^{2}\right)$ is located in the central part of the basin. A large geographic distance from the surrounding oceans, as well as the presence of the rain-shadow effect due to the surrounding orographic conditions, is responsible for the arid climate of the Zhungarer Basin, which is necessary for the creation of the sand desert. Most rivers in the Yili watershed converged into the Yili River at their lower reaches. The Yili River is a large international river running from the northeast Borohoro Mountains and the southeast Halik Mountains, which are both branches of the eastern Tianshan Mountains, and flowing westward through the Yili basin into Kazakstan (Fig. 1c). It drains igneous and metamorphic Precambrian $(A n €)$ and Variscan $\left(\gamma_{4}\right)$ granite, Carboniferous $\left(\mathrm{C}_{1}, \mathrm{C}_{2+3}\right)$ carbonatite and limestone, and Quaternary sediments (Ma 2002) (Fig. 1f). The
Yili River is about $430 \mathrm{~km}$ long inside the Yili watershed and contains three major tributaries in the catchment: the Kashi River in the northeast, the Gongnais River in the east, and the Terkers River in the south and southeast. Much of the drainage areas of the tributaries are dominated by sedimentary, mostly carbonate, lithologies (Fig. 1f). The Erlqis watershed has headwaters in the southern slopes of the Altai Mountains (Fig. 1e). Rivers converge into the Erlqis River at their lower reaches, and the Erlqis River is also a large international river, flowing through Kazakstan northward through Russia and finally into the Arctic Ocean. The stem channel of the Erlqis River is about $500 \mathrm{~km}$ long inside the Erlqis watershed. The Buerjin River is one of the most important tributaries of the Erlqis River and is about $250 \mathrm{~km}$ long and originates in the glaciers of the Youyi Mountains (4373 m asl). The lithologic outcrops in the catchment are mainly the Devonian marine carbonate, clastite (D2, D2+3), and the igneous Variscan $\left(\gamma_{4}\right)$ granite and Quaternary sediments (Ma 2002) (Fig. 1f).

\section{Methods}

Water samples

To understand the general spatial variation in ground water geochemistry over the study area, a well inventory survey was carried out during the 2008 summer-autumn season. Stream fluxes of most rivers in northern Xinjiang in this season are at falling stage (Zhu et al. 2013a). The sampling work choosing at this season is in order to avoid the influence of the springmelt water peak on regional hydrology and water chemistry, and the chemical compositions of water at this season are roughly close to the annual average in arid region (Huh et al. 1998a, b). A Garmin global positioning system (GPS) was used for location and elevation readings and being cross-checked against topographic sheets made available by the Geological Survey of China (GSC). Sampling sites were selected to represent different geological formations, land-use patterns, and the varying topography of the study area. Forty-eight water samples were collected under natural flow conditions in 1-L polyethylene bottles from various parts of the Yili, Zhungarer, and Erlqis watersheds (Fig. 1e), including river stems, stream channels, hill slopes, wells, lakes, ponds, man-made trenches, and reservoirs. Taking into account that the tributaries reflect a much 
broader variety of geological, biological, and population patterns than main stem rivers (Pawellek et al. 2002), it was of interest to sample tributary water to look for the common features reflected in their hydrochemistry. Some pristine streams draining forested catchments were chosen in the Tianshan and the Altai Mountains. All waters were surface-sampled except for the well water extracted from pump shafts. Most water samples were colorless, but a few were yellow, gray, or turbid due to dissolved iron contents or suspended solid particles. The colored river water samples primarily drained through the south and north piedmont areas of the Tianshan Mountains, with deep coves of loess and loess-like soil. Because no river and spring exist in the hinterland of the Gulbantonggute Desert, no surface water samples were collected for comparison with samples from other areas.

Physiochemical analysis

Physical properties of the water sample such as $\mathrm{pH}$, temperature, and total dissolved solids (TDS) were measured in situ with a portable multiparameter analyzer (Eijkelkamp 18.28) that was calibrated with standard solutions. The major chemical constituents were analyzed at the Institute of Geology and Geophysics, Chinese Academy of Sciences (IGGCAS). All samples were filtered through $0.45-\mu \mathrm{m}$ Millipore membrane filters. The water samples for cation analysis were acidified with hyper-pure $\mathrm{HNO}_{3}$ below $\mathrm{pH}$ 4.5. Cations and anions were determined by ion chromatography (IC, Dionex 600) with deionized water $(\mathrm{EC}<2.1 \mu \mathrm{S} / \mathrm{cm})$ as the dilute base. The eluents used were $20 \mathrm{mmol} / \mathrm{L}$ methanesulfonic acid (MSA) at $\mathrm{pH} 4.5$ and conductivity of approximately $400 \mu \mathrm{S} / \mathrm{cm}$ for cation analysis and $3.5 \mathrm{mmol} / \mathrm{L} \mathrm{Na}_{2} \mathrm{CO}_{3}$ and $1.0 \mathrm{mmol} / \mathrm{L} \mathrm{NaHCO}_{3}$ at pH 8.5 for anion analysis, respectively. Standards and blanks were analyzed at the beginning of each sample run, were inserted between every five field samples, and were analyzed at the back end of each sample run for quality assurance/quality control (QA/QC). The alkalinity was measured with a Hach digital titrator using the Gran method (Wetzel and Likens 2000) within 3 days after sampling.

\section{Data interpretation}

As the consequence of the physiochemical analysis, each sampling site is characterized by a large number of chemical and physical variables, making the regional hydrogeochemical study a multivariate problem. In order to characterize and interpret these data, conventional techniques and multivariate statistics were used. For the conventional techniques, Stiff diagrams and Piper plots are constructed in this study using the techniques outlined in Stiff (1951) and Piper (1944), respectively.

Using multivariate statistics to understand the physiochemistry of water samples is to investigate statistical relationships among their dissolved constituents and environmental parameters. Statistical associations do not necessarily establish cause-and-effect relationships, but do present the information in a compact format and can assist in generating hypothesis for the interpretation of hydrochemical processes (Guler et al. 2002; Guler and Thyne 2004). Two multivariate statistical methods were applied in this study using the Statistical Package for the Social Sciences (SPSS Version 17.0) program: the hierarchical cluster analysis (HCA) and the principal component analysis (PCA). The description of HCA and PCA techniques and the methodology used for their application in ground water composition have been detailed in previous studies (e.g., Stetzenbach et al. 2001; Guler et al. 2002; Guler and Thyne 2004; Dragon 2006; Helstrup et al. 2007; Papatheodorou et al. 2007; Van den Brink et al. 2007; Cloutier et al. 2008; Yidana 2010; Monjerezi et al. 2011; Zghibi et al. 2014; Dragon and Gorski 2015). In this study, the parameters involved in the statistics include major constituents $\mathrm{Ca}^{2+}, \mathrm{Mg}^{2+}, \mathrm{Na}^{+}, \mathrm{K}^{+}, \mathrm{HCO}_{3}{ }^{-}, \mathrm{Cl}^{-}$, $\mathrm{SO}_{4}{ }^{2-}, \mathrm{NO}_{3}{ }^{-}, \mathrm{pH}$, and TDS, as well as locality elevations and AMP of the sampling sites. Because the distributions of most part of these parameters are highly positively skewed (Online Supplementary Fig. S1) and their frequency diagrams do not follow a normal distribution, chemical parameters were thus log-transformed, except for $\mathrm{Ca}^{2+}, \mathrm{pH}$, elevation, and AMP whose distributions are close to normal (Online Supplementary Fig. S1). Finally, standardization was applied to the eight lognormal and four normal distributions to ensure that each variable is weighted equally (Online Supplementary Fig. S2). Standardization of the data $\left(X_{i}\right)$ results in new values $\left(Z_{i}\right)$ that have zero mean and are measured in units of standard deviation $(s)$. The standardized data are obtained by subtracting the mean of the distribution from each data and divided by the standard deviation of the distribution, $Z_{i}=\left(X_{i}-\right.$ mean $) / s$ (Davis 1986). Log transformation of positively skewed 
chemical parameters as well as data standardization is commonly done in multivariate statistical analysis (Guler et al. 2002; Cloutier et al. 2008).

\section{Results}

\section{Conventional analysis}

The basic statistical summary of the analysis results of physical and chemical parameters of the water samples is presented in Table 1. The data of the samples in Table 1 show up the quite different total dissolved solids (TDS), which ranges from 24.6 to $6200 \mathrm{mg} / \mathrm{L}$. Generally, more than half of the analyzed waters belong to fresh water, because the TDS does not exceed $1000 \mathrm{mg} / \mathrm{L}$ (Fig. 2). In contrast, the remainders from the Zhungarer basin are more saline, belonging to brackish water (TDS 1-10 g/L) (Fig. 2). $\mathrm{pH}$ varies significantly among the sampling sites with a range of 7.009.81 (average 7.87), most part of which is lower than 8.5 (Fig. 2). The $\mathrm{pH}$ values are represented as alkaline medium, and high values are measured in the desert lands of the Zhungarer Basin or in the areas in which carbonate rocks interacted with water body in the Yili watershed (Fig. 2). Therefore,

Table 1 Statistical summary of the physical parameters and major ion concentrations determined in the studied water samples

\begin{tabular}{llllll}
\hline Parameter & Maximum & Minimum & Average & Median & SD \\
\hline $\mathrm{pH}$ & 9.81 & 7.00 & - & 7.85 & 0.47 \\
$\mathrm{EC}(\mu \mathrm{s} / \mathrm{cm})$ & 5380 & 46.3 & 864 & 352 & 1258 \\
$\mathrm{TDS}(\mathrm{mg} / \mathrm{L})$ & 6200 & 24.6 & 580 & 186 & 1071 \\
$\mathrm{Li}^{+}(\mathrm{mg} / \mathrm{L})$ & 0.13 & nd & 0.02 & 0.01 & 0.02 \\
$\mathrm{Na}^{+}(\mathrm{mg} / \mathrm{L})$ & 1673 & 1.66 & 105 & 6.86 & 281 \\
$\mathrm{NH}_{4}{ }^{+}(\mathrm{mg} / \mathrm{L})$ & 0.17 & nd & 0.02 & $\mathrm{nd}$ & 0.04 \\
$\mathrm{~K}^{+}(\mathrm{mg} / \mathrm{L})$ & 77.7 & 0.49 & 8.48 & 1.63 & 17.4 \\
$\mathrm{Mg}^{2+}(\mathrm{mg} / \mathrm{L})$ & 190 & 0.63 & 27.2 & 6.49 & 49.5 \\
$\mathrm{Ca}^{2+}(\mathrm{mg} / \mathrm{L})$ & 91.9 & 3.05 & 29.1 & 26.4 & 16.7 \\
$\mathrm{~F}^{-}(\mathrm{mg} / \mathrm{L})$ & 3.04 & 0.02 & 0.31 & 0.18 & 0.51 \\
$\mathrm{Cl}^{-}(\mathrm{mg} / \mathrm{L})$ & 648 & 1.83 & 74.5 & 6.91 & 160 \\
$\mathrm{NO}_{3}{ }^{-}(\mathrm{mg} / \mathrm{L})$ & 36.5 & nd & 4.96 & 2.88 & 6.62 \\
$\mathrm{SO}_{4}{ }^{2-}(\mathrm{mg} / \mathrm{L})$ & 2655 & 2.52 & 205 & 45.3 & 437 \\
$\mathrm{HCO}_{3}{ }^{-}(\mathrm{mg} / \mathrm{L})$ & 799 & 9.76 & 117 & 69.4 & 142 \\
\hline
\end{tabular}

$T H$ total hardness, SAR sodium adsorption ratio high $\mathrm{pH}$ value is dependent on hydrogeochemical properties of the drainage basin. $\mathrm{pH}$ range between 6.0 and 8.5 indicates the productive (or fertile) nature of water body (Garg et al. 2010), so the ground waters in the study area are under the eutrophication control limit values $(\mathrm{pH}, 8.5 \max )$ according to the values of World Health recommended maximum permissible limits (WHO 2008).

The relationship between major ions provides information for the evaluation of solute sources and a first insight on the chemical classification of ground water. The Piper's diagram, which plotted the proportions in milliequivalents per liter of the major cations and anions, shows the main hydrogeochemical features, as well as their spatial evolution (Fig. 3). Base on major anions and cations, four main water types are classified in the study area, ranging in composition from the $\mathrm{Ca}-$ $\mathrm{HCO}_{3}$, and $\mathrm{Ca}-\mathrm{Mg}-\mathrm{HCO}_{3}-\mathrm{SO}_{4}$ to $\mathrm{Ca}-\mathrm{SO}_{4}$ (or Ca-Mg$\mathrm{SO}_{4}$ ) and $\mathrm{Na}-\mathrm{SO}_{4}$ type. A distinct shift of the water sample points is evident in both the cation and anion triangles. In the anion diagram, sample points are generally shifted towards the sulfate apex. These samples contain gradually high TDS concentrations. In the cation diagram, in turn, the samples are shifted towards the sodium apex. The chemical evolution of the water sample distribution is evident in the trend of the diamond-shaped diagram that is from the $\mathrm{Ca}-\mathrm{HCO}_{3}$ towards the $\mathrm{Ca}-\mathrm{Mg}-\mathrm{HCO}_{3}-\mathrm{SO}_{4}$ and $\mathrm{Ca}-\mathrm{Mg}-\mathrm{SO}_{4}$ and finally towards the $\mathrm{Na}_{-} \mathrm{SO}_{4}$ water type (Fig. 3a). For all of the three watersheds, Ca-bicarbonate and $\mathrm{Ca}$ sulfate facies are predominated, although the Zhungarer watershed shows a tendency towards a Na-sulfate composition (Fig. 3b). The $\mathrm{Ca}-\mathrm{HCO}_{3}$ and Ca-non-dominant anion (NDA) types mainly occur in the montane areas and the low-pitched piedmont zones. The $\mathrm{Ca}-\mathrm{SO}_{4}$ and $\mathrm{Na}-\mathrm{SO}_{4}$ types are mostly distributed in the transition band between oasis and desert plains (playa areas). Mg-type water only exists in the Sailimu Lake.

Stiff diagram (Stiff 1951) are constructed for all the water data and are displayed in Fig. 4. The water from several mountain sites has narrow, funnel-shaped Stiff diagrams (e.g., samples 14, $36,43,44,46$, and 48) that indicate low ionic concentrations possibly due to short contact time of the water with the ground materials. The rest of the Stiff diagrams show wide shapes, clearly revealing their water types identified in the Piper diagram (Fig. 3). 
Fig. 2 Values of the TDS and $\mathrm{pH}$ of the water samples analyzed in this study

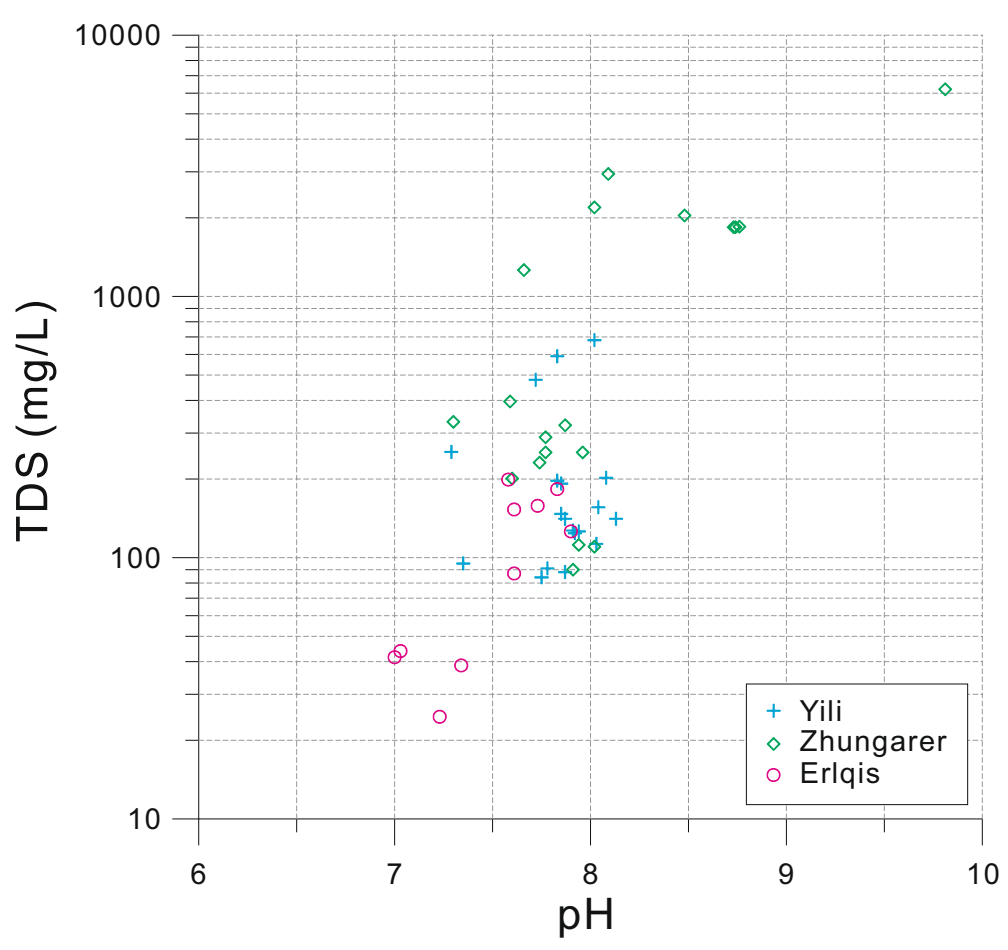

the data set was analyzed using the Q-mode HCA technique. The main result of the HCA performed on the 48 ground water samples is shown in a dendrogram (Fig. 5). For this HCA project, the squared Euclidean distance was chosen as the distance measure, or similarity measurement, between sampling sites (Q-mode). The samples with the large similarity are first grouped.
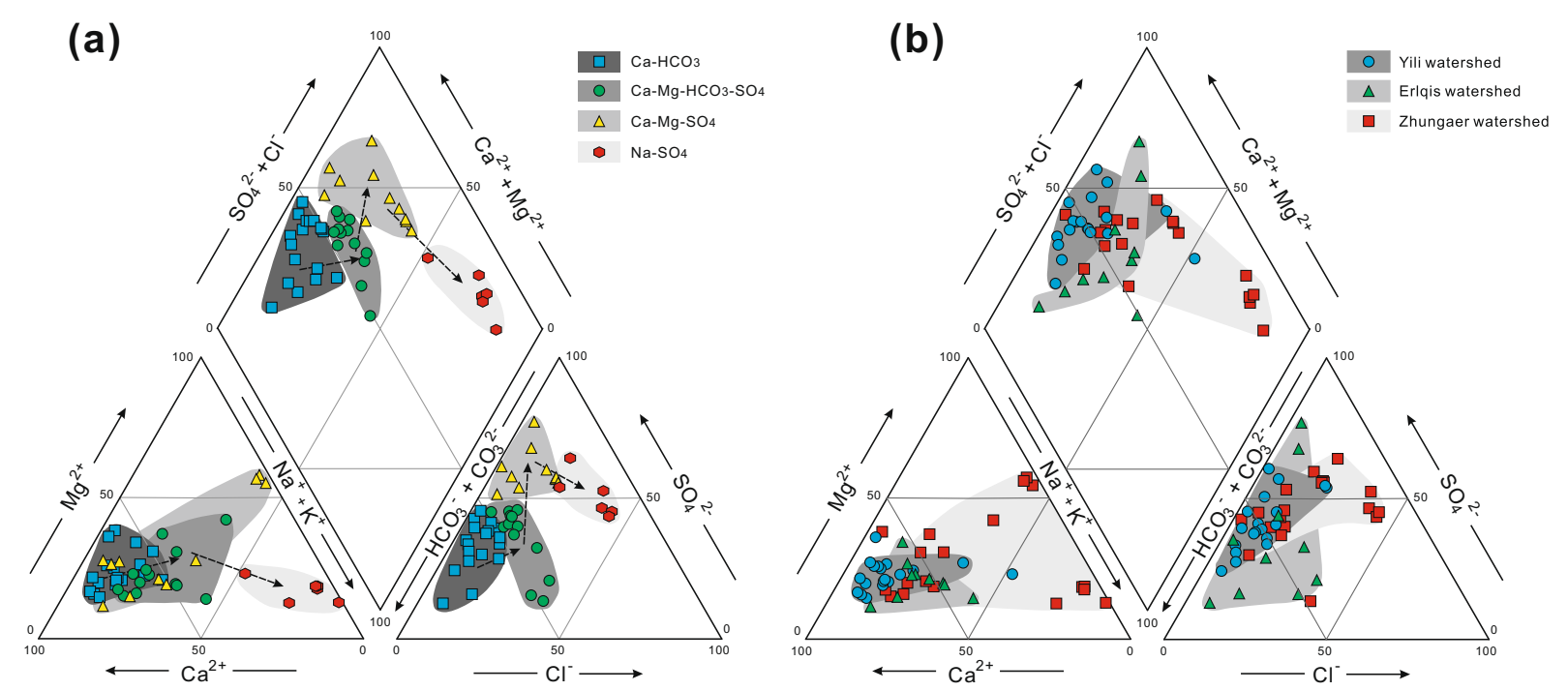

Fig. 3 Piper diagram of the chemical classification and evolution of ground water samples in the study area: a classified by water types (starting with recharge water and ending with playa-area discharge waters, as shown by the arrows) and $\mathbf{b}$ classified by watershed 


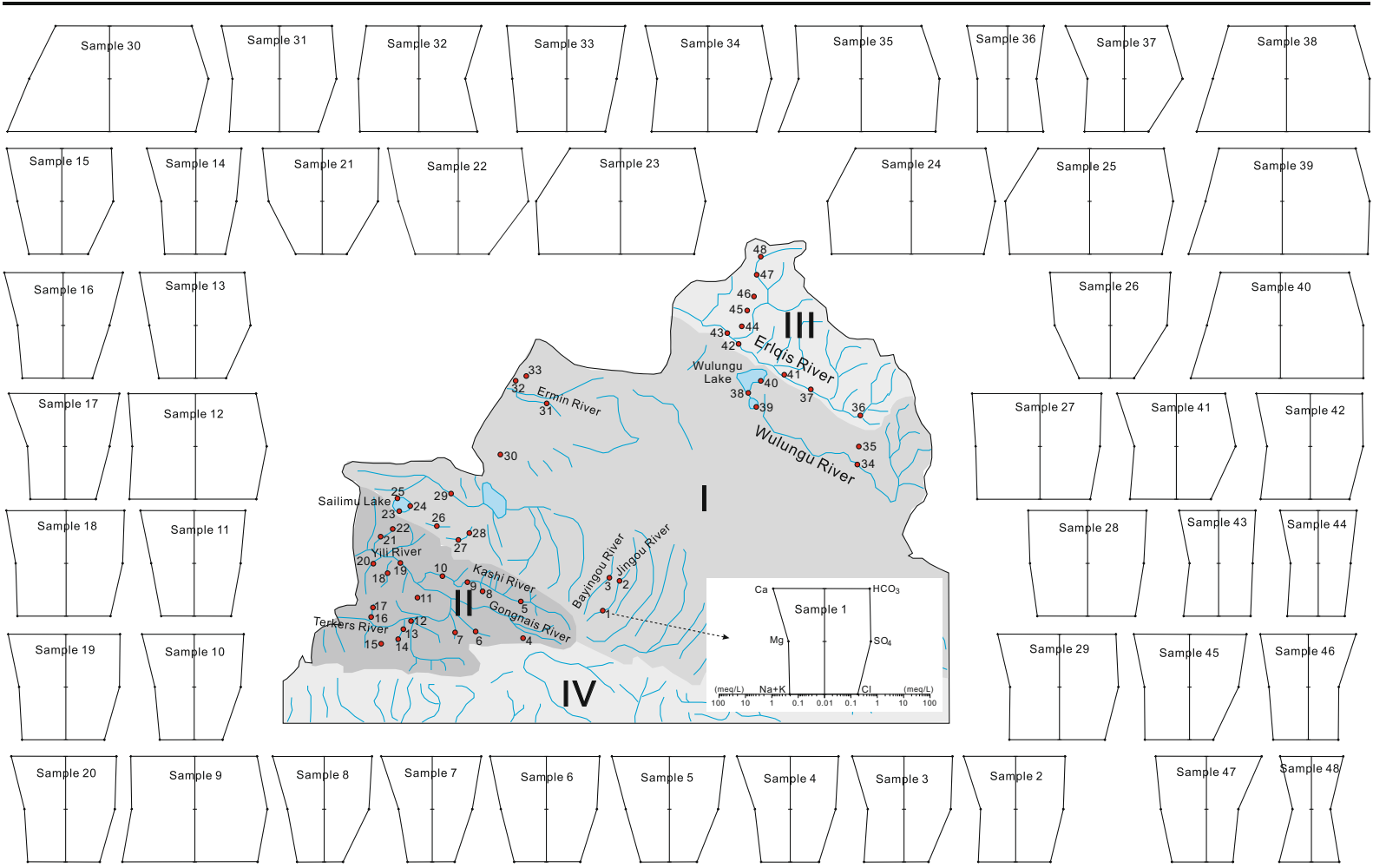

Fig. 4 Stiff diagrams of the water samples together with their geographical localities in the study area

Next, groups of samples are joined with a linkage rule, and the steps are repeated until all observations have been classified. For the linkage rule, "between-groups linkage" method was adopted.

The classification of the samples into clusters is based on a visual observation of the dendrogram. In this study, the phenon line was drawn across the dendrogram at a linkage distance of about 7 (Fig. 5). Thus, samples with a linkage distance lower than 7 are grouped into the same cluster. This position of the phenon line allows a division of the dendrogram into seven clusters of ground water samples, named $\mathrm{C} 1-\mathrm{C} 7$. As revealed by Stiff diagram, the seven clusters gave the most satisfactory results at forming geochemically distinct water types (Fig. 5), thus fulfilling the objectives of the classification method.

Observation of the dendrogram reveals some indications of the level of similarity between the seven clusters (Fig. 5). Samples from C5, C6, and C7 are linked to the other clusters at an elevated distance, indicating that these samples are geochemically distinct from the ones of the other four clusters. Among these four clusters, C4 is the less similar as it has a high linkage distance to clusters $\mathrm{C} 1-\mathrm{C} 3 . \mathrm{C} 1$ and $\mathrm{C} 2$ have the shortest linkage distance between the defined clusters and, thus, have the greatest similarity among all clusters. It can thus be expected that the geochemistry of $\mathrm{C} 2$ samples would have similarities with the ones of $\mathrm{C} 1$. Similarities between the geochemistry of $\mathrm{C} 1$ samples are expected as all the samples in the cluster are linked at a short distance.

To describe the characteristics of each cluster of samples, Table 2 presents the mean values of geochemical and physical data for these clusters. The mean values of the major ions were used to determine a mean ground water type for each cluster and are represented on Stiff diagrams (Fig. 5). The descriptive statistics and the Stiff diagrams indicate that the seven clusters are geochemically distinct (Fig. 5). Samples from $\mathrm{C} 1$ have $\mathrm{Ca}-\mathrm{HCO}_{3}$ water types and are most widely distributed in the study area with relatively low solute concentrations. Samples from $\mathrm{C} 2$ have $\mathrm{Ca}-\mathrm{Mg}-\mathrm{HCO}_{3}-\mathrm{SO}_{4}$ type and are characterized by the highest concentrations in $\mathrm{NO}_{3}$ and the lowest elevation (Fig. 5, Table 2). Samples from C3 are $\mathrm{Ca}-\mathrm{SO}_{4}$ type and have the highest concentrations for $\mathrm{Ca}^{2+}$ and AMP. Samples from C4 have mixed cationsanions water type and are characterized by lowest TDS and $\mathrm{pH}$. Samples from C5, C6, and C7 are all lake 


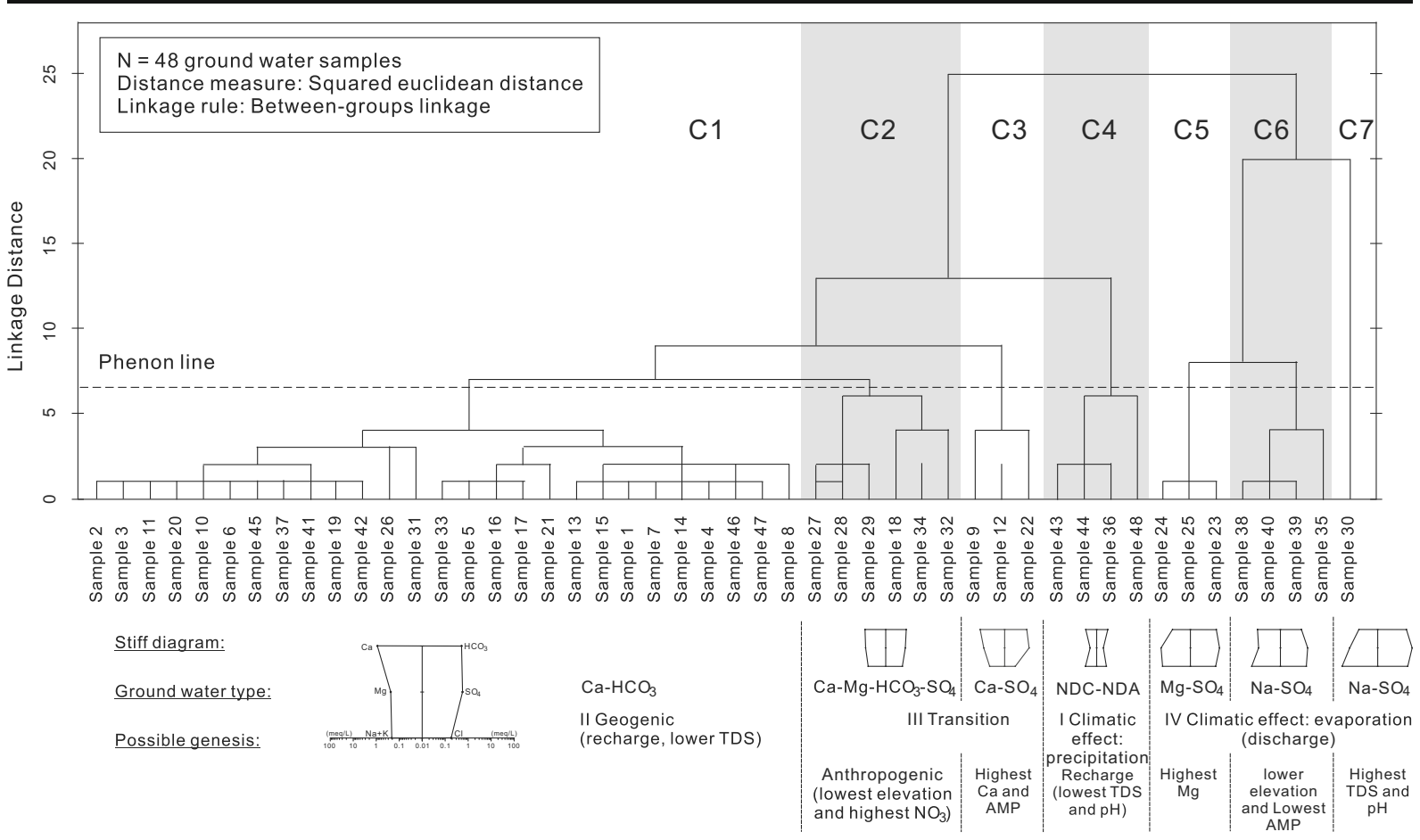

Fig. 5 Dendrogram of Q-mode hierarchical cluster analysis (HCA) for the samples in this study, showing associations between samples from different parts of the hydroclimatic system and the

waters with high TDS values and have $\mathrm{Mg}-\mathrm{SO}_{4}$ and $\mathrm{Na}-$ $\mathrm{SO}_{4}$ types, respectively. The main differences between these three clusters are that $\mathrm{C} 5$ has the highest $\mathrm{Mg}^{2+}$ concentrations and C6 has the lowest AMP and the division into seven clusters and the typical Stiff diagram of each cluster. The horizontal dash line defines "phenon line" (after Guler et al. 2002)

lowest elevation. $\mathrm{C} 7$ has the particularity of having the highest TDS and $\mathrm{pH}$ and the lowest $\mathrm{NO}_{3}$ of all clusters (Fig. 5, Table 2). Here we have to say that $\mathrm{C} 7$ is only based on one sample collected from the extreme

Table 2 Geochemical and physical characteristics of each HCA cluster (mean value)

\begin{tabular}{llllllll}
\hline Parameters & $\mathrm{C} 1$ & $\mathrm{C} 2$ & $\mathrm{C} 3$ & $\mathrm{C} 4$ & $\mathrm{C} 5$ & $\mathrm{C} 6$ & $\mathrm{C} 7$ \\
\hline$N$ & 27 & 6 & 3 & 4 & 3 & 4 & 1 \\
$\mathrm{Na}^{+}(\mathrm{mg} / \mathrm{L})$ & 5.84 & 24.6 & 68.6 & 3.13 & 241 & 534 & $\mathbf{1 6 7 3}$ \\
$\mathrm{K}^{+}(\mathrm{mg} / \mathrm{L})$ & 1.45 & 2.42 & 3.33 & 1.16 & 23.4 & 53.2 & $\mathbf{5 6 . 0}$ \\
$\mathrm{Mg}^{2+}(\mathrm{mg} / \mathrm{L})$ & 5.57 & 15.3 & 27.7 & 1.31 & $\mathbf{1 8 8}$ & 68.8 & 135 \\
$\mathrm{Ca}^{2+}(\mathrm{mg} / \mathrm{L})$ & 24.9 & 37.9 & $\mathbf{7 1 . 7}$ & 5.44 & 20.2 & 45.1 & 22.3 \\
$\mathrm{Cl}^{-}(\mathrm{mg} / \mathrm{L})$ & 5.47 & 28.0 & 53.8 & 5.28 & 203 & 455 & $\mathbf{6 4 8}$ \\
$\mathrm{NO}_{3}^{-}(\mathrm{mg} / \mathrm{L})$ & 4.93 & $\mathbf{1 1 . 6}$ & 4.832 & 1.42 & 2.49 & 1.91 & 0.01 \\
$\mathrm{SO}_{4}{ }^{2-}(\mathrm{mg} / \mathrm{L})$ & 37.9 & 75.2 & 241 & 6.49 & 736 & 689 & $\mathbf{2 6 5 5}$ \\
$\mathrm{HCO}_{3}^{-}(\mathrm{mg} / \mathrm{L})$ & 58.5 & 104 & 138 & 14.1 & 398 & 241 & $\mathbf{7 9 8}$ \\
$\mathrm{pH}$ & 7.84 & 7.60 & 7.86 & 7.15 & 8.74 & 8.06 & $\mathbf{9 . 8 1}$ \\
$\mathrm{TDS}(\mathrm{mg} / \mathrm{L})$ & 145 & 307 & 583 & 37.2 & 1843 & 2108 & $\mathbf{6 2 0 0}$ \\
Elevation $(\mathrm{m}$, asl $)$ & 1134 & 511 & 1589 & 808 & $\mathbf{2 0 7 9}$ & 592 & 1885 \\
$\mathrm{AMP}(\mathrm{mm})$ & 267 & 161 & $\mathbf{4 1 3}$ & 241 & 340 & 140 & 215 \\
\hline
\end{tabular}

Values in bold are the highest values; values in italics are the lowest values $N$ number of samples 
conditions and its representativeness is maybe low. It should be noted that the database at present may suffer from limitation due to the large size of the studied watersheds and the subsampling process.

Results of the PCA

The PCA is a data transformation technique that attempts to reveal a simple underlying structure that is assumed to exist within a multivariate dataset (Davis 1986). The most important feature of this technique is its ability to reduce a large number of variables down to a smaller number of factors (for instance, reducing 12 variables to 3 variables in this study). Because the mean and variance values of geochemical data are easily biased by the presence of extremes
(Online Supplementary Fig. S1), the standardization of the data is performed firstly (Online Supplementary Fig. S2). From the standardized geochemical dataset in this study, principal components were extracted from the symmetrical correlation matrix computed for the 12 variables. The number of components to keep was based on the Kaiser criterion, for which only the components with eigenvalues greater than 1 are retained. As a result, only the first three components extracted have eigenvalues greater than 1 . They account for $87.1 \%$ of the total variance in the dataset. To maximize the variance of the first three principal axes, the Varimax normalized rotation was applied (e.g., Adams et al. 2001; Aiuppa et al. 2003; Cloutier et al. 2008). A descriptive term is defined (a)

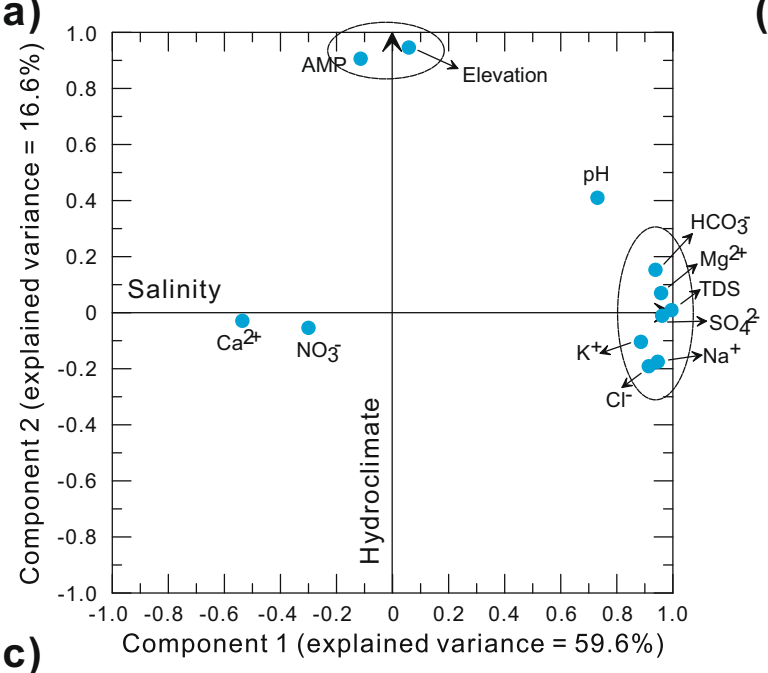

(c)

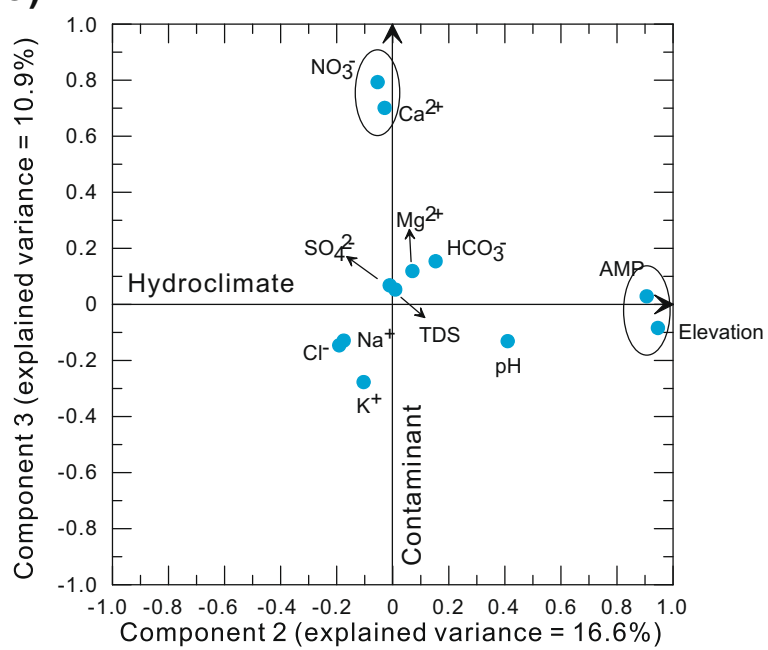

(b)

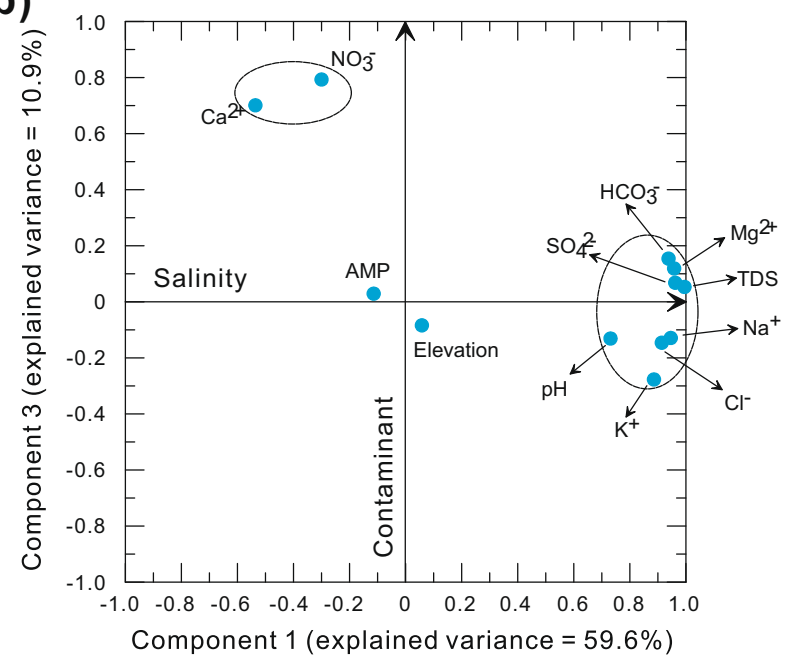

Fig. 6 a-c Plot of the R-mode PCA loadings for the first three components with Varimax normalized rotation 
for each of the three components based on their characteristic loadings (Fig. 6). Because of the association of major ions and TDS, component 1 is defined as the "salinity" or "geogenic" component in reference to the total solute content. Component 2 is defined as the "hydroclimate" or "geomorphclimatic" component in reference to the sampling-site topography and precipitation. Component 3 is defined as the "contaminant" or "anthropogenic" component because of its highly positive loadings in $\mathrm{NO}_{3}{ }^{-}$and $\mathrm{Ca}^{2+}$, which are often related to anthropogenic materials.

Table 3 presents the principal component loadings for these three components, as well as their respective explained variance. Loadings, which represent the importance of the variables for the components, are underlined for values greater than 0.7 (Table 3). Each component is characterized by a few high loadings and many near-zero low loadings, fulfilling the objectives of the rotation. The three components explain 59.6, 16.6, and $10.9 \%$ of the variance (Table 3 ), respectively, and thus account for the majority of the variance in the original dataset. The total of the other components (eigenvalues $<1$ ) explains only about $12.9 \%$ of variance,

Table 3 Principal component loadings and explained variance for the three components with Varimax normalized rotation

\begin{tabular}{lccc}
\hline Parameters & Component 1 & Component 2 & Component 3 \\
\hline $\mathrm{Na}^{+}$ & 0.946 & -0.175 & -0.129 \\
$\mathrm{~K}^{+}$ & 0.886 & -0.104 & -0.277 \\
$\mathrm{Mg}^{2+}$ & 0.958 & 0.070 & 0.119 \\
$\mathrm{Ca}^{2+}$ & -0.536 & -0.029 & 0.701 \\
$\mathrm{Cl}^{-}$ & 0.914 & -0.191 & -0.146 \\
$\mathrm{NO}_{3}{ }^{-}$ & -0.300 & -0.054 & 0.793 \\
$\mathrm{SO}_{4}{ }^{2-}$ & 0.962 & -0.011 & 0.068 \\
$\mathrm{HCO}_{3}{ }^{-}$ & 0.938 & 0.153 & 0.154 \\
$\mathrm{pH}^{\mathrm{TDS}}$ & 0.731 & 0.410 & -0.131 \\
Elevation & 0.995 & 0.009 & 0.053 \\
$\mathrm{AMP}$ & 0.058 & 0.946 & -0.084 \\
Explained variance & 7.158 & 1.994 & 0.029 \\
Explained & 59.6 & 16.6 & 1.306 \\
$\quad$ variance (\%) & & 76.2 & 87.1 \\
Cumulative \% & 59.6 & & \\
$\quad$ of variance & & & \\
\hline Values itics & & & \\
\hline
\end{tabular}

Values in italics have loadings $>0.7$ indicating that these components are related to more local effects than the first three components.

Component 1 explains the greatest amount of the variance $(59.6 \%)$ and is characterized by highly positive loadings in most of ions $\left(\mathrm{Na}^{+}, \mathrm{K}^{+}, \mathrm{Mg}^{2+}, \mathrm{Cl}^{-}, \mathrm{SO}_{4}{ }^{2}\right.$ ${ }^{-}, \mathrm{HCO}_{3}{ }^{-}$), $\mathrm{pH}$, and TDS (Table 3). Component 2 $(16.6 \%)$ is characterized by highly positive loadings in sampling-site elevation and AMP, and component 3 $(10.9 \%)$ shows highly positive loadings in $\mathrm{NO}_{3}{ }^{-}$and $\mathrm{Ca}^{2+}$ (Table 3).

The PCA-defined new variables can be displayed in a scatter diagram, presenting the individual variables or water samples as points in a low-dimensional (generally 2-D) space. Figures 6 and 7 show the results of the PCA analysis of the 12 variables and 48 samples. Figure 6 illustrates the R-mode characterizations of 12 variables by showing the position of the loading of each parameter in the plane defined by the axes of components 1,2 , and 3 , respectively.

In statistical and mathematical language, the PCA method is used to investigate the degree of continuity or clustering of the samples and to determine if overlapping water types exist within the data (Guler et al. 2002). Figure 7 presents plots of the principal component scores for the first three components shown in Table 3 and Fig. 6. The scores represent the influence of the component on each of the ground water samples. We developed this plot to integrate and interpret the PCA and HCA results within the study area settings. The Q-mode scatter of points in Fig. 7 suggests that there is continuous variation of the chemical and physical properties of the studied samples.

In Fig. 7, the samples studied are labeled with their respective clusters defined previously by the HCA analysis (seen in Table 2 and Fig. 5). Grouping of samples is possible into this plane defined by the axes of component 1 , the salinity, component 2 , the hydroclimate, and component 3, the contaminant. Almost all of the samples are distributed in the upper-right (positive value) areas of the PCA score diagrams (Fig. 7), suggesting that the water samples are influenced by elevated conditions of salinity, hydroclimate, and contamination in the study area. These positive scores of the samples also indicate that all of the ground water samples are to some extent dependent upon or related to the geogenic, geomorphclimatic, and anthropogenic processes in the northern Xinjiang watersheds. 
(a)

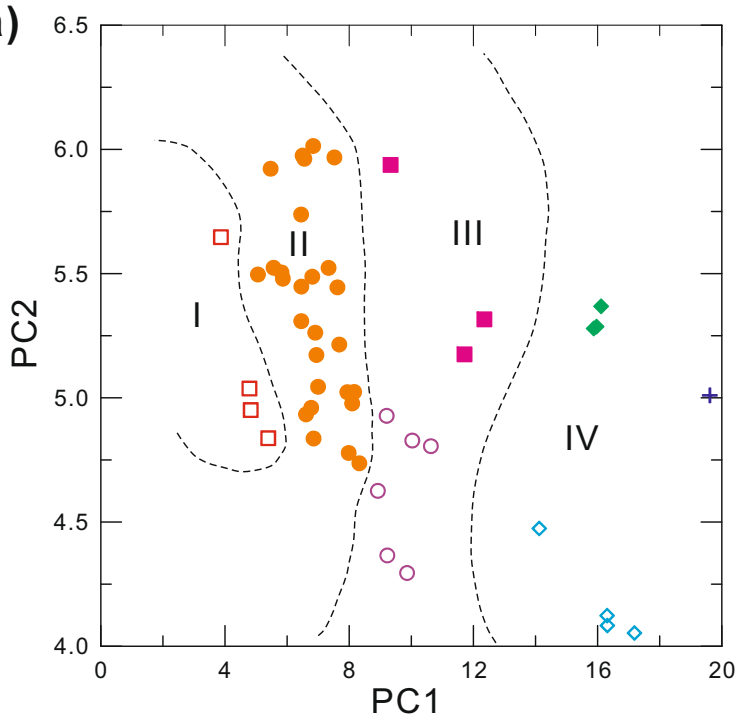

(c)

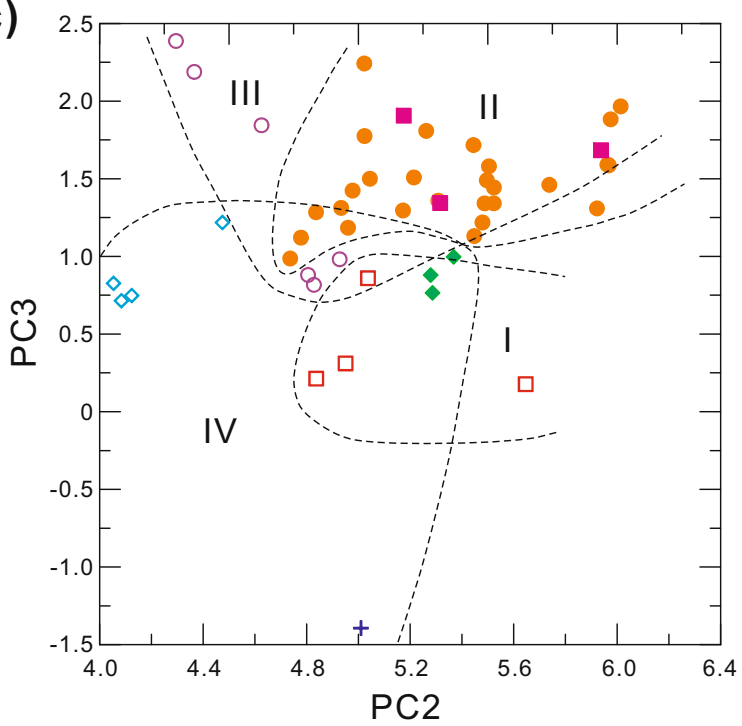

(b)

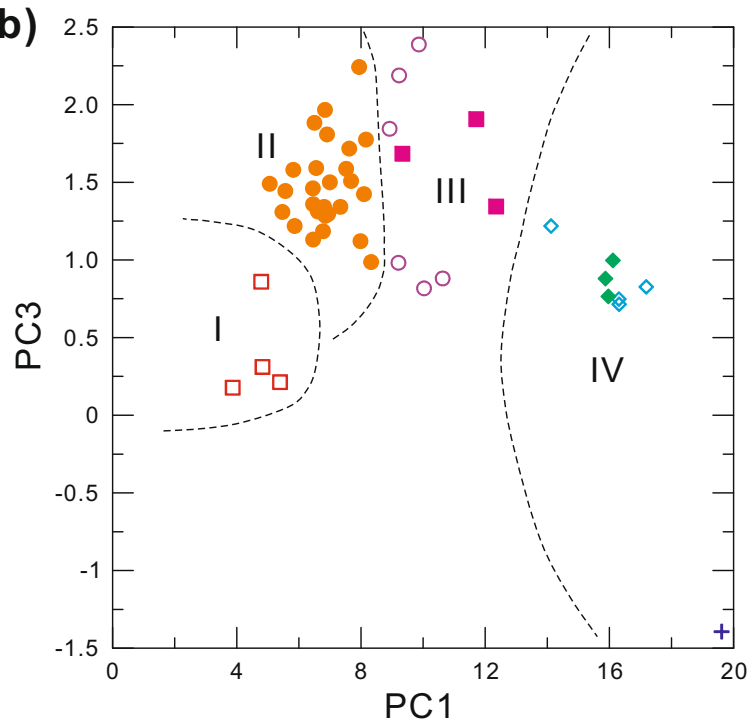

Fig. 7 a-c Plot of Q-mode PCA scores for the first three components showing the distribution of HCA-derived clusters of the ground water samples

Plots in Fig. $7 \mathrm{a}-\mathrm{c}$ are efficient at separating the various clusters in the plane defined by the axes of components 1,2 , and 3 , respectively. They can be reasonably separated into four zones: I zone (C4), II zone (C1), III zone $(\mathrm{C} 2+\mathrm{C} 3)$, and IV zone $(\mathrm{C} 5+\mathrm{C} 6+$ $\mathrm{C} 7)$. These diagrams provide a good visualization of the various ground water types found in the northern Xinjiang, as well as insight into the geochemical processes and recharge regime responsible for these variations.

Samples from I and II zones $(\mathrm{C} 4+\mathrm{C} 1)$ are located in the upper-left side of the diagram
(Fig. 7a), and thus associated to elevated hydroclimate degree coupled to low salinity. Samples from III zone $(\mathrm{Ca}+\mathrm{C} 3)$ are associated to moderately elevated salinity and evidently elevated contamination but coupled to low hydroclimate degree (Fig. 7a, b). Samples from IV zone (C5+ $\mathrm{C} 6+\mathrm{C} 7)$ are associated mainly to elevated salinity coupled to low or inverse hydroclimate degree (Fig. 7a, b). According to their PCA scores and water types, we deduce I and II zones as recharge area, III zone as transition area, and IV zone as discharge area, which were shown in Fig. 5. 


\section{Discussion}

Genesis and evolution of the ground waters

\section{Ionic ratios of natural water}

Ground water flowing through different aquifer systems may be identified and differentiated by their salinity levels and ionic ratios. Genesis of ground waters in the study area is defined by calculating the hydrochemical parameters $\mathrm{Na} / \mathrm{Cl}, \mathrm{Ca} / \mathrm{Mg}$, and $\mathrm{SO}_{4} / \mathrm{Cl}(\mathrm{meq} / \mathrm{L})$ and comparing these parameters with the standard values of normal sea water (Table 4).

$\mathrm{Na} / \mathrm{Cl}$ ratio indicates sources of salinity during ground water flow (Cartwright and Weaver 2005). Most of water samples in the study area showed that sodium ions exceed chloride ions (Fig. 8a), except for sample 36 in Erlqis and sample 11 in Yili, whose ratios were less than unity reflecting marine salt origin. The high sodium concentration in ground water indicates addition of sodium to water through the weathering/ dissolution and ion exchange processes which withdraws $\mathrm{Ca}$ and gives $\mathrm{Na}$ to the solution. The presence of shale and sandstone in the study area promotes the suggested dissolution and ion exchange processes.
$\mathrm{Ca} / \mathrm{Mg}$ ratios suggest the dissolution of calcite and dolomite present in the aquifer materials. Generally, values close to unity indicate dissolution of dolomite (Maya and Loucks 1995). The $\mathrm{Ca} / \mathrm{Mg}$ ratios for sample 9 and sample 28 are very close to unity (Table 4). However, most of the samples showed higher ratio (Table 4, Fig. 8b) which interpreted as being due to greater gypsum or calcite dissolution, except for the samples in the desert area of the Zhungarer Basin, wherein the ratio was less than unity reflecting strong Ca precipitation by evaporation effect. Dissolution processes is expected to be more common than ion exchange processes in the study area due to the presence of the arid climate and evaporites.

Ratios of $\mathrm{SO}_{4} / \mathrm{Cl}$ and $\mathrm{HCO}_{3} / \mathrm{Cl}$ reflect anion evolution during hydrogeochemical processes along flow paths (Fig. 8c, d) (Han et al. 2009). The $\mathrm{SO}_{4} / \mathrm{Cl}$ ratio could be taken as a good indicator for detecting any excess of sulfate in ground water associated with gypsum dissolution and leaching of terrestrial salts or oxidation of sulfides in the aquifers (Noh et al. 2009). The $\mathrm{SO}_{4}$ excess represents either the oxidation of rock sulfur or the mixing of two different water masses with an oxidizing recharge. In the case of water mixing, the $\mathrm{Cl}$ concentration varies. It is thus necessary to normalize

Table 4 Calculated ion ratios of analyzed water samples in northern Xinjiang compared to equivalent standard of sea water

\begin{tabular}{|c|c|c|c|c|c|c|c|c|c|c|c|}
\hline Sample points & $\mathrm{Na} / \mathrm{Cl}$ & $\mathrm{Ca} / \mathrm{Mg}$ & $\mathrm{SO}_{4} / \mathrm{Cl}$ & Sample point & $\mathrm{Na} / \mathrm{Cl}$ & $\mathrm{Ca} / \mathrm{Mg}$ & $\mathrm{SO}_{4} / \mathrm{Cl}$ & Sample point & $\mathrm{Na} / \mathrm{Cl}$ & $\mathrm{Ca} / \mathrm{Mg}$ & $\mathrm{SO}_{4} / \mathrm{Cl}$ \\
\hline Sea water & 0.854 & 0.194 & 0.100 & \multicolumn{4}{|l|}{ Yili watershed } & \multicolumn{4}{|c|}{ Zhungarer watershed } \\
\hline Yili watershed & & & & Sample 20 & 1.235 & 3.162 & 3.708 & Sample 33 & 1.965 & 1.599 & 2.688 \\
\hline Sample 4 & 0.865 & 4.752 & 4.225 & Sample 21 & 1.028 & 1.669 & 15.073 & Sample 34 & 1.880 & 2.749 & 3.639 \\
\hline Sample 5 & 0.863 & 3.352 & 6.379 & Sample 22 & 2.771 & 2.445 & 31.526 & Sample 35 & 1.923 & 1.314 & 1.407 \\
\hline Sample 6 & 0.741 & 2.553 & 4.254 & \multicolumn{4}{|c|}{ Zhungarer watershed } & Sample 38 & 1.768 & 0.257 & 1.035 \\
\hline Sample 7 & 1.017 & 4.575 & 4.657 & Sample 1 & 0.859 & 3.810 & 3.133 & Sample 39 & 1.903 & 0.308 & 1.168 \\
\hline Sample 8 & 1.469 & 3.628 & 9.598 & Sample 2 & 1.112 & 4.367 & 3.079 & Sample 40 & 1.682 & 0.303 & 0.999 \\
\hline Sample 9 & 2.302 & 1.079 & 2.332 & Sample 3 & 3.150 & 3.869 & 6.971 & \multicolumn{4}{|c|}{ Erlqis watershed } \\
\hline Sample 10 & 1.454 & 3.076 & 4.883 & Sample 23 & 1.865 & 0.052 & 2.671 & Sample 36 & 0.527 & 2.439 & 0.564 \\
\hline Sample 11 & 0.581 & 2.575 & 2.301 & Sample 24 & 1.788 & 0.087 & 2.692 & Sample 37 & 3.495 & 6.747 & 19.460 \\
\hline Sample 12 & 1.515 & 1.402 & 2.463 & Sample 25 & 1.825 & 0.057 & 2.647 & Sample 41 & 2.654 & 4.500 & 8.597 \\
\hline Sample 13 & 1.402 & 2.318 & 8.407 & Sample 26 & 1.624 & 1.504 & 17.766 & Sample 42 & 2.296 & 2.524 & 3.246 \\
\hline Sample 14 & 1.017 & 3.483 & 2.635 & Sample 27 & 1.670 & 1.366 & 2.334 & Sample 43 & 1.106 & 2.472 & 1.204 \\
\hline Sample 15 & 1.385 & 2.508 & 9.039 & Sample 28 & 1.196 & 1.162 & 2.098 & Sample 44 & 1.248 & 2.485 & 1.672 \\
\hline Sample 16 & 2.382 & 3.196 & 4.398 & Sample 29 & 1.438 & 2.933 & 3.262 & Sample 45 & 5.239 & 2.522 & 9.068 \\
\hline Sample 17 & 1.167 & 5.069 & 3.311 & Sample 30 & 3.979 & 0.100 & 3.022 & Sample 46 & 1.202 & 2.123 & 1.041 \\
\hline Sample 18 & 1.355 & 2.248 & 2.884 & Sample 31 & 2.582 & 2.552 & 4.820 & Sample 47 & 1.475 & 1.569 & 1.605 \\
\hline Sample 19 & 1.444 & 2.591 & 3.746 & Sample 32 & 1.004 & 0.501 & 0.354 & Sample 48 & 1.097 & 2.957 & 0.466 \\
\hline
\end{tabular}


(a)

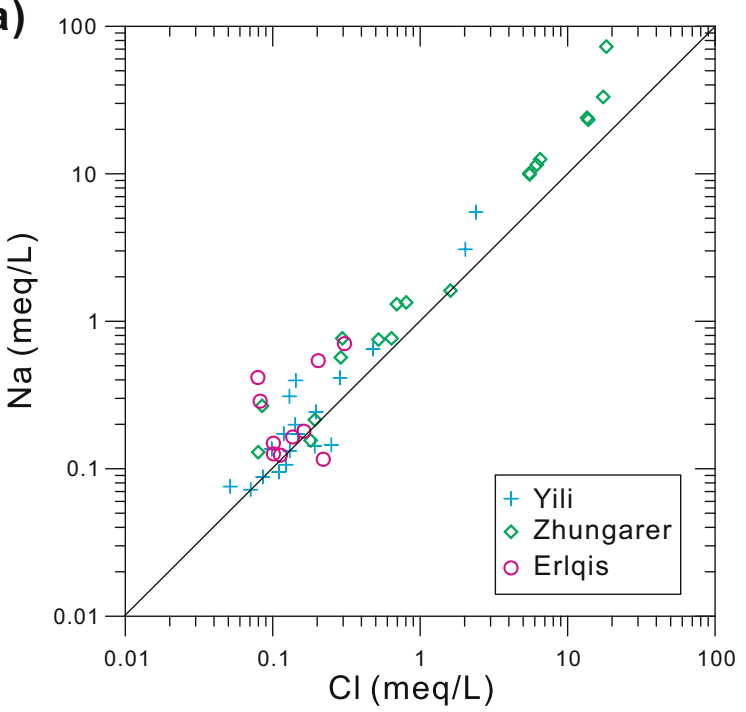

(c)

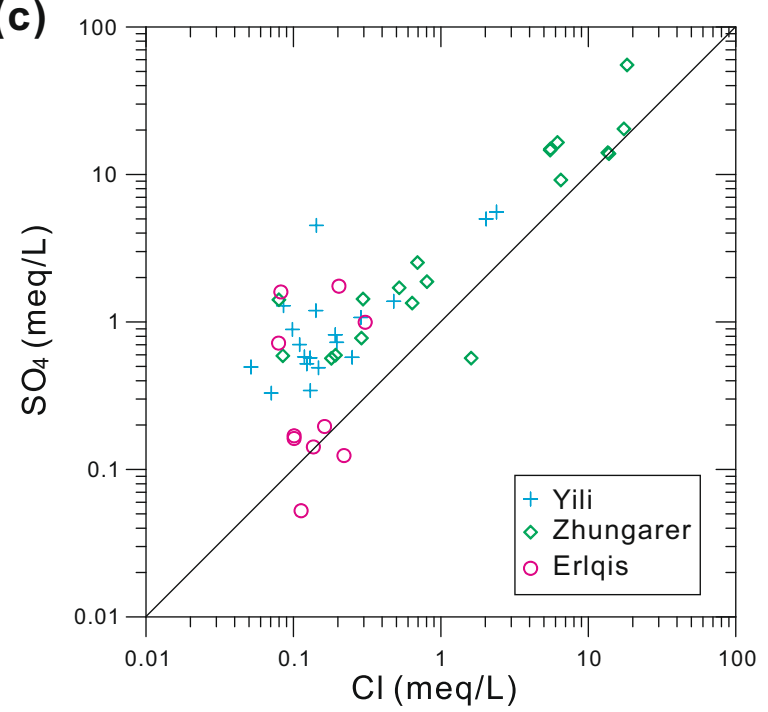

(b)

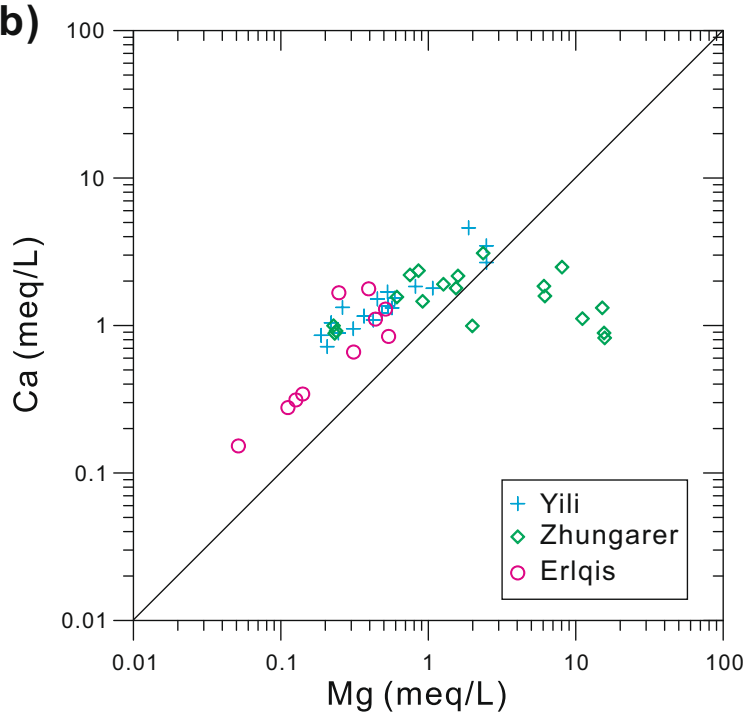

(d)

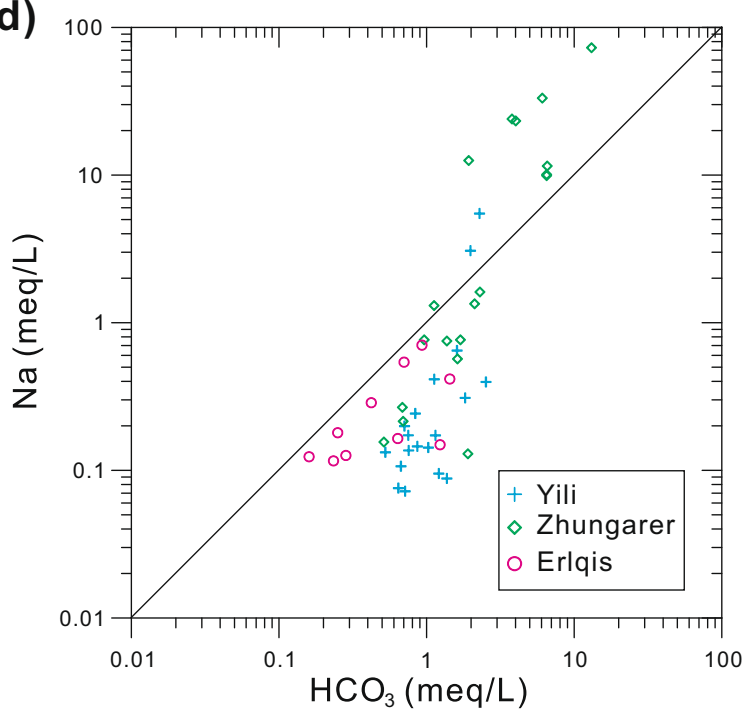

Fig. 8 Scatter diagram of the ionic concentrations of $\mathrm{Na}^{+}$vs. $\mathrm{Cl}^{-}, \mathrm{Mg}^{2+}$ vs. $\mathrm{Ca}^{2+}, \mathrm{Cl}^{-}$vs. $\mathrm{SO}_{4}{ }^{2-}$, and $\mathrm{HCO}_{3}{ }^{-}$vs. $\mathrm{Na}^{+}$of the studied waters

the $\mathrm{SO}_{4}$ concentration with respect to $\mathrm{Cl}$ concentration to evidence the mixing process. The standard values of chloride and sulfate for sea water are 19,400 and $2530 \mathrm{mg} / \mathrm{L}$, respectively. The simple mixing relationship between two defined water bodies can be well represented on a $\mathrm{Cl}$ vs. $\mathrm{SO}_{4} / \mathrm{Cl}$ graph (Fig. 9) (Fontes et al. 1988). The two curves inside the figure represent the upper and lower boundaries of a conservative mixing zone. The ratios for most part of water samples in this study are higher than unity (except for Sample 32, 36, and 48) (Table 4), and most part of samples are beyond the boundary area of a conservative mixing zone (except for several samples in the Erlqis and Zhungarer) (Fig. 9). This indicates a less degree of mixing process occur in the study area. The higher ratio indicates a supplementary source of sulfate possible due to the dissolution of gypsum.

The main chemical water types in the study area identified using the Piper trilinear diagram (Fig. 3) and the Stiff diagram (Fig. 4) are $\mathrm{Ca}-\mathrm{HCO}_{3}$ and $\mathrm{Ca}-\mathrm{SO}_{4}$ and no chloride water type occurred, which reflect the intermediate and immature water phase in the study drainage system. For these waters, the change of water type from $\mathrm{Ca}-\mathrm{HCO}_{3}$ to $\mathrm{Ca}-\mathrm{Mg}-\mathrm{HCO}_{3}-\mathrm{SO}_{4}$ and further to $\mathrm{Ca}-\mathrm{Mg}$ - 
Fig. 9 Mass ratio of $\mathrm{SO}_{4}{ }^{2-} / \mathrm{Cl}$ vs. $\mathrm{Cl}$

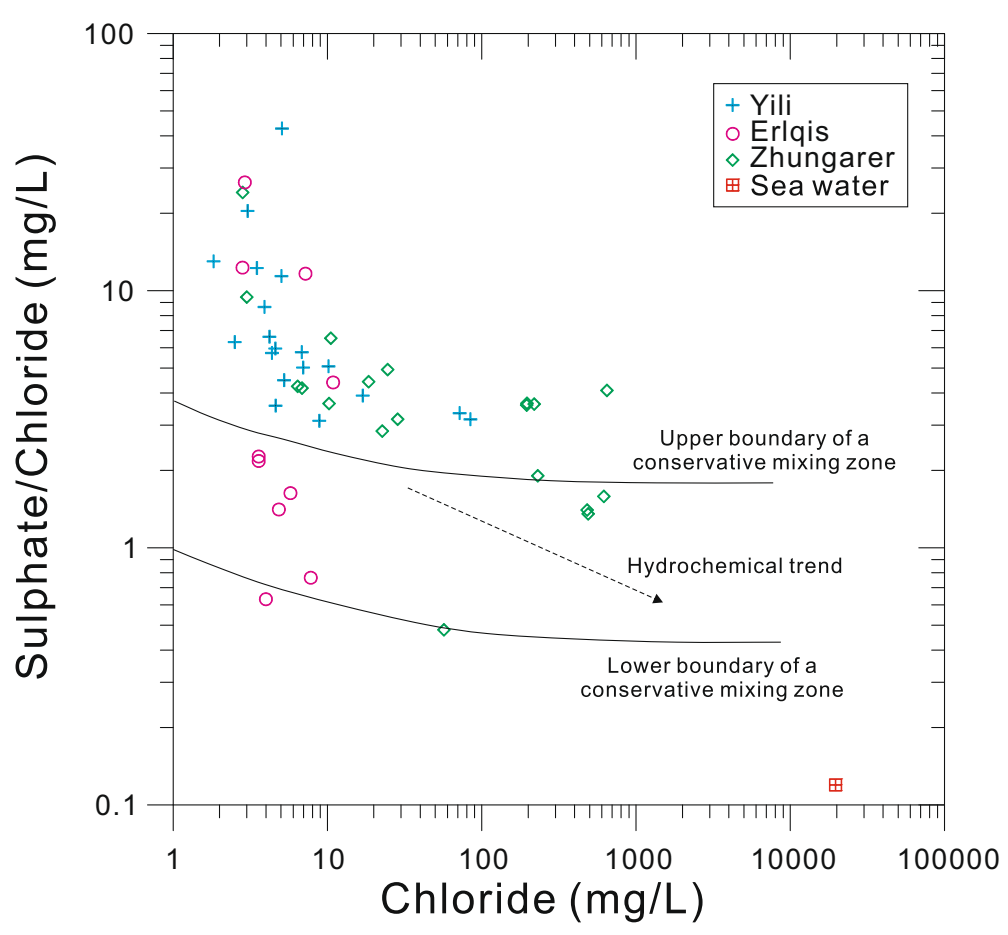

$\mathrm{SO}_{4}$ and $\mathrm{Na}_{-} \mathrm{SO}_{4}$ (Fig. 3a) marks ions and water evolution during hydrogeochemical processes along flow paths and water circulation. The addition of salts into the channels along the flow is reflected by shift of the water from $\mathrm{Ca}$ to $\mathrm{Na}$. This is confirmed by the values of $\mathrm{Ca} / \mathrm{Mg}$ ratios and $\mathrm{Na} / \mathrm{Cl}$ ratios (Fig. $8 \mathrm{a}, \mathrm{b}$ ).

\section{Ground water evolution along the flow path}

Trends of ground water chemistry along its flow paths may give clues to the hydrochemical processes prevailing in the drainage basin (Rosen and Jones 1998; Zhu et al. 2007). A series of plots illustrate the key hydrochemical trends along the elevation degree of water sample localities (Figs. 10 and 11). The TDS values of the studied waters from different river basins are relatively low in the area with higher elevation (mountain or alpine areas), and there is a gradual increase along the decrease of topographical degree (Fig. 10). The behaviors of ion concentrations, such as sodium, chloride, and sulfate (Fig. 11b, f, h), are similar to the TDS. This pattern of major ions and TDS increasing with decreasing elevation of sample localities appears to define the topographic flow path of alpine area recharge moving towards the playa areas.
Chloride can be used as a conservative reference element against which to study the water-rock interaction. Chloride concentrations are typically between 1.83 and $648 \mathrm{mg} / \mathrm{L}$ at the studied watersheds. A principal feature of the ground waters is the enrichment in sodium relative to chloride (Fig. 8a). These high $\mathrm{Na} / \mathrm{Cl}$ ratios are indicative of strong water-rock interaction. Sulfate exhibits a similar evolution pattern with chloride with more enrichment (average wt $\mathrm{SO}_{4} / \mathrm{Cl}=6.73$ ) (Figs. 8c and 9).

A rough increase in $\mathrm{pH}$ along with the increase of elevation was observed (Fig. 11a), which is accompanied with decrease in calcium, magnesium, and alkalinity (primarily as $\mathrm{HCO}_{3}$ ) along with the increase of elevation (Fig. 11d, e, i). This is expected as precipitation (recharge water) typically has a lower $\mathrm{pH}$ than the circumneutral native water. Thus, when precipitation mixes with ground water, carbonate minerals will dissolve, increasing the calcium, magnesium, and alkalinity concentrations in solution. The observed increases in these major ions (sodium, calcium, magnesium, chloride, and sulfate) along with the decrease of elevation (Fig. 11) were likely due to the increases of solutes from dissolution of solid-phase constituents and evaporationcondensation processes, whereas decreases in these 
(a)

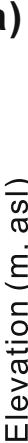

(c)

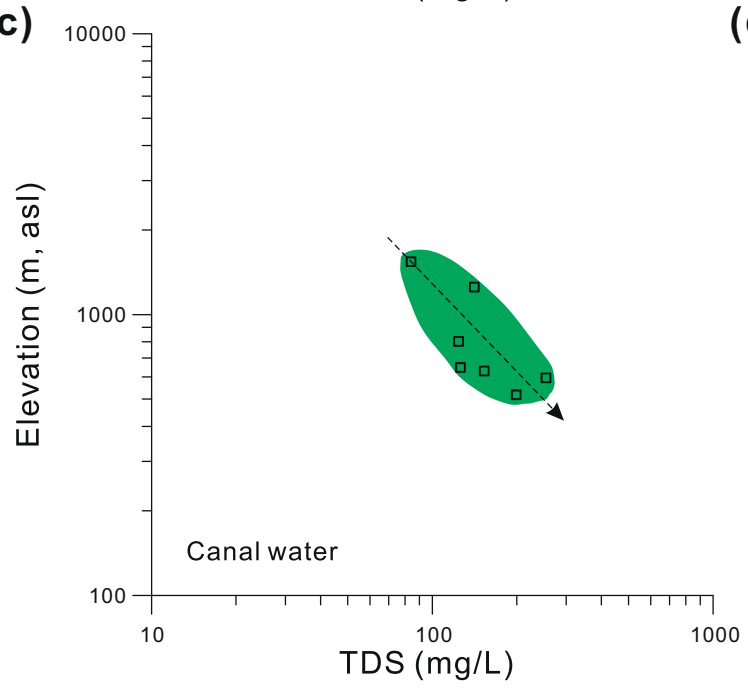

(b)

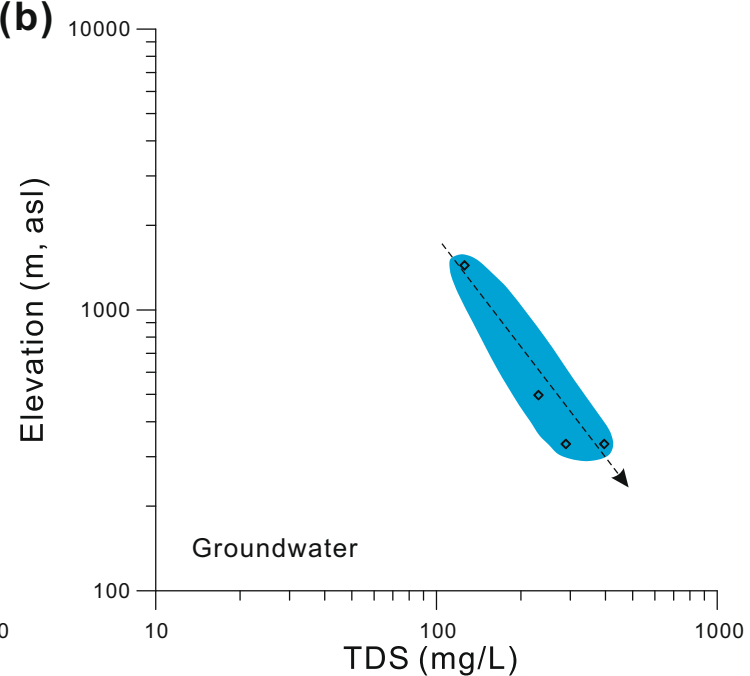

(d)

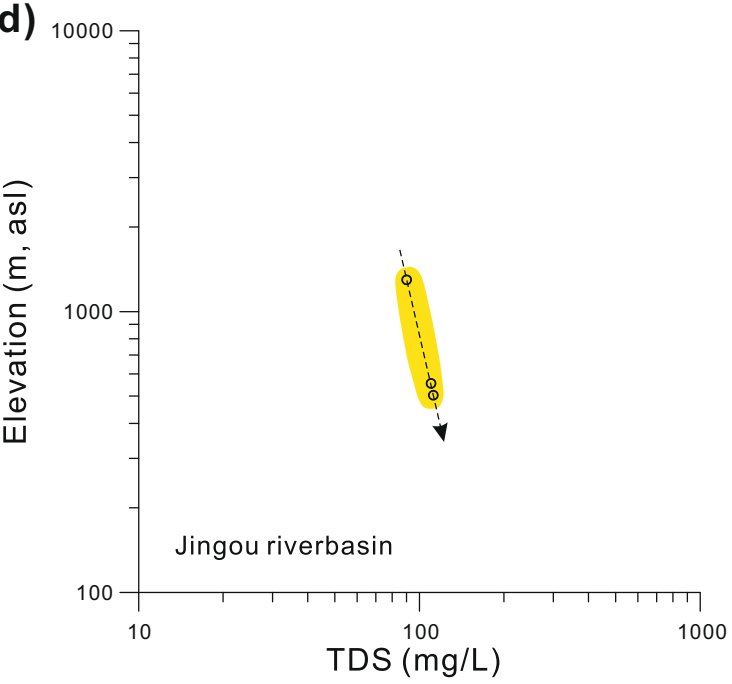

(e)

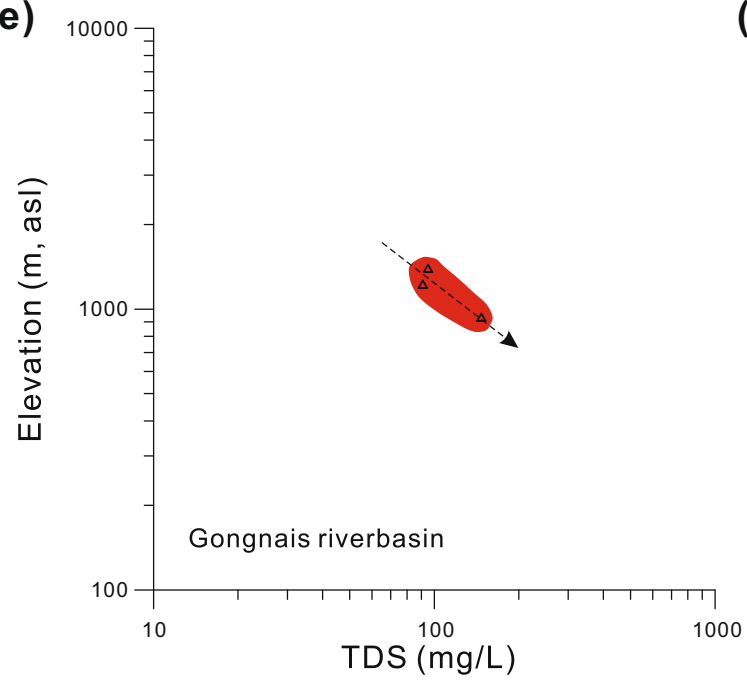

(f)

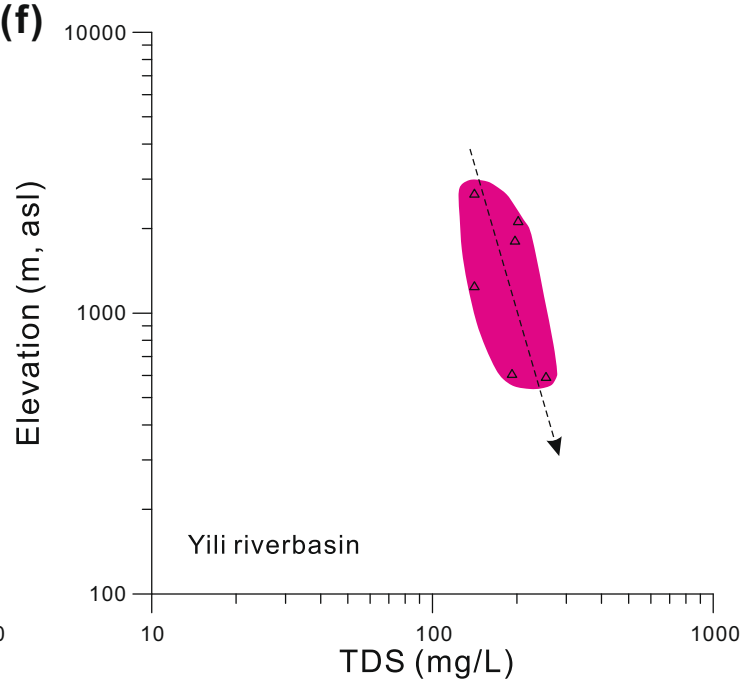

Fig. 10 a-f TDS variations along with the locality elevations of the studied water samples 

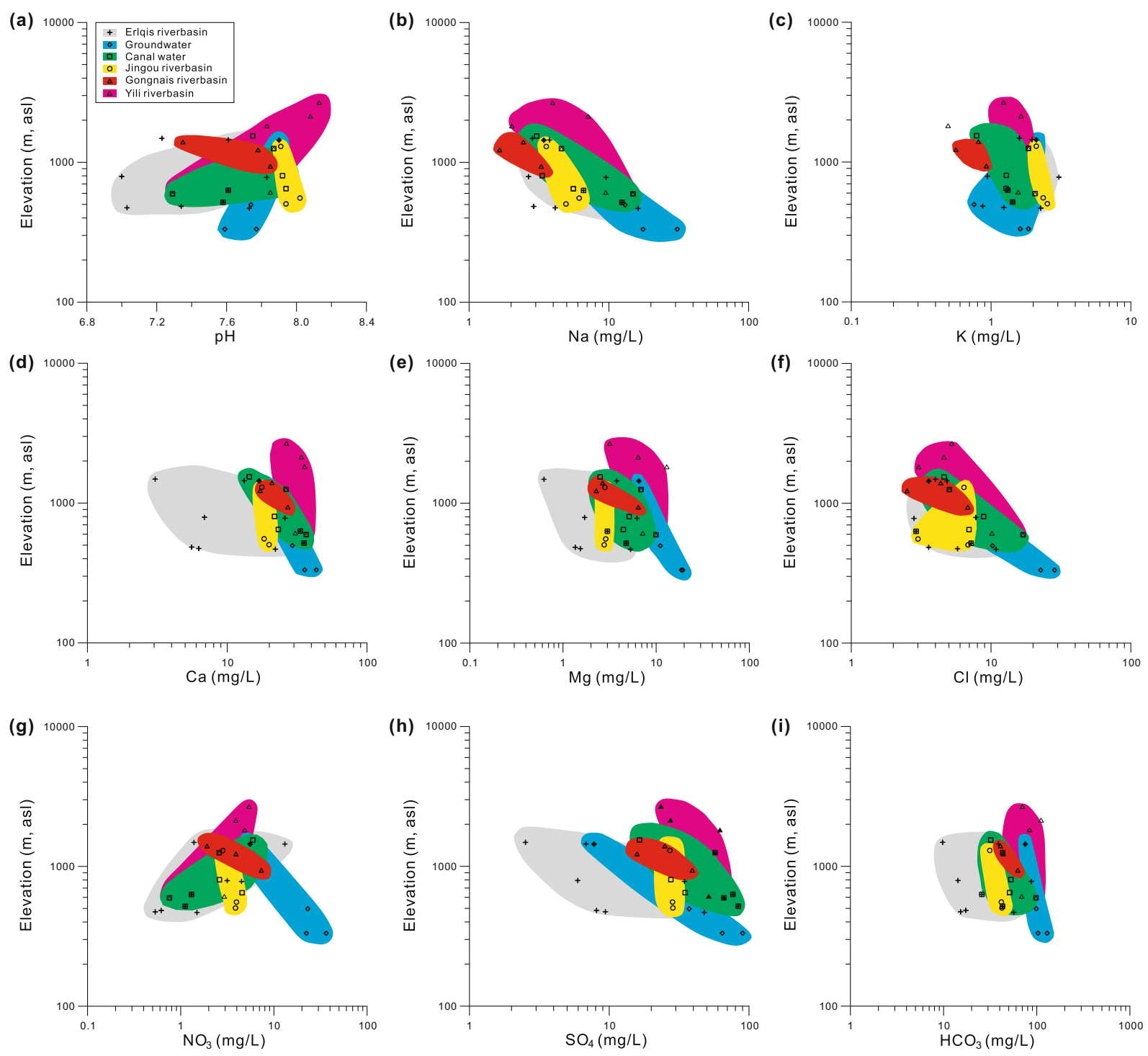

Fig. 11 a-i Physical parameter $(\mathrm{pH})$ and major ion variations along the locality elevations of the studied water samples

solutes along with the increase of elevation can be explained by dilution with recharge water.

The extremely low TDS of the high-elevation waters (mountain waters) suggests that the surface water does not remain in contact with the surface bedrock long enough for significant dissolution to occur. This also suggests relatively short flow paths for these waters. Because dilute snowmelt runoff (dominated by $\mathrm{Ca}$ and $\mathrm{HCO}_{3}$ ions) is an active agent in chemical weathering reactions that are occurring in the alpine watersheds (Zhu et al. 2011), these trends indicate that the reactions during the short flow times in the mountain regions of the study area are important for the initial hydrochemical evolution (precipitation recharge to $\mathrm{Ca}-\mathrm{HCO}_{3}$ groups). The final phase of hydrochemical evolution occurs near the playa area (low elevations) where a very large increase in TDS are linked to increase in $\mathrm{Na}, \mathrm{SO}_{4}$, and $\mathrm{Cl}$, suggesting that dissolution of salts and evapotranspiration-concentration process are a significant control during the stage.

\section{Identification of natural (geogenic) and anthropogenic groups of hydrogeochemical processes}

The investigation of ground water genesis and evolution is usually complicated because changes 
of ground water chemistry caused by anthropogenic and natural (geogenic) hydrogeochemical processes overlap. Studies have demonstrated that the application of factor analysis (FA) and PCA in regional hydrogeochemical research is a reliable method for differentiation of natural and anthropogenic processes affecting ground water chemistry (Guler and Thyne 2004; Dragon 2006; Cloutier et al. 2008; Huang et al. 2013; Dragon and Gorski 2009, 2015).

As demonstrated previously, component 1 is defined as salinity by highly positive loadings in TDS and most parts of major ions (Fig. 6a, b). Many other regional hydrochemical studies have also produced a first component with high loadings of elements associated to different salinization processes, such as ion-filtration processes (Usunoff and Guzman-Guzman 1989), infiltration of saline surface water (Adams et al. 2001), and seawater intrusion or infiltration from salt manufacturing (Wang et al. 2007). The significance of the other two components 2 and 3 , in terms of regional processes, is not as important as that of the first component 1 as they explain a lower percentage of the variance. This PCA pattern emphasizes that the geogenic processes are more significant than the geomorphclimatic processes and the anthropogenic processes in the study area.

Geochemical processes being important for component 1 could include weathering and dissolution of silicate, carbonate, and sulfate minerals. Zhu et al. $(2011,2013 \mathrm{~b})$ presented data suggesting the occurrence and weathering of silicate, carbonate, and sulfate dissolution based on the mineralogy of geological units and mineral saturation indices. The negative loading of $\mathrm{Ca}^{2+}$ in this study, in opposition to the positive loadings in other major ions of the component 1 (Fig. 6a), is possibly consistent with the occurrence of ion exchange with $\mathrm{Na}^{+}$and pollution processes (Fig. 6a, b). Additional data, including detailed anthropology, hydrogeology, and climatology, would be needed to better understand the geochemical processes associated to the components 2 and 3 .

Recharge mechanisms of the ground waters

In the large scale, the northern Xinjiang drainage system is characterized by its location in the semi-arid to hyperarid basins and range provinces (Fig. 1d), which is marked by alternating mountains and alluvial basins. In a classic basin-and-range ground water system in arid environment, water flows from recharge areas in the mountains to discharge areas in adjacent valleys and alluvial basins (Maxey 1968). Discharge areas are generally occupied by playas where large amounts of salt deposition occur due to evaporation. From the results of principal component scores (PCA) and ground water clusters (HCA), it becomes apparent that the studied region can be divided into three main hydrological areas: the recharge area (I and II zone in Figs. 5 and 7), the transition area (III zone in Figs. 5 and 7), and the discharge area (IV zone in Figs. 5 and 7). This division is insightful for the interpretation of the recharge mechanism of ground water in northern Xinjiang drainage system.

The mountain and pediment areas in the three watersheds, dominated by samples of cluster $\mathrm{C} 1$ and $\mathrm{C} 4$, are relatively wetter regions with a strong hydraulic gradient and consist of Paleozoic carbonate (Fig. 1f). The water samples from these areas are characterized mainly by $\mathrm{Ca}-\mathrm{HCO}_{3}$ water type $(\mathrm{C} 1)$ and mixed water types with low solute concentrations (C4), thus belonging to modern recharge water. $\mathrm{C} 2+\mathrm{C} 3$ are characterized by $\mathrm{Ca}$ $\mathrm{Mg}-\mathrm{HCO}_{3}-\mathrm{SO}_{4}$ and $\mathrm{Ca}-\mathrm{SO}_{4}$ water types with moderately hydraulic gradient, and this could indicate the evolution of recharge to evolved ground water (transitional zone). For lake and pond waters with a relatively low hydraulic gradient (playa areas), $\mathrm{C} 5+\mathrm{C} 6+\mathrm{C} 7$ are mainly characterized by $\mathrm{Na}-\mathrm{SO}_{4}$ or $\mathrm{Mg}_{-} \mathrm{SO}_{4}$ with high TDS values, thus belonging to discharge water.

In hydrological view, the possible mechanisms of ground water recharge (especially river and shallow ground water) in northern Xinjiang may be (a) direct infiltration of rainwater (summer and winter atmospheric precipitation), (b) direct recharge from seasonal snow and melt water, and (3) recharge from potential deep ground water. The first two processes are thought to be more important than the third one, because the study area contains various ranges in a desert landscape. Based on the tectonic structure of mountain-basin couples, the recharge of the shallow ground water is mainly through infiltration of seasonal snow and ice-melt water from mountain areas and local precipitation that infiltrates downwards quickly due to the loose nature of the regolith. Because of the large temporal and spatial variability of rainfall, infiltration is related to the amount of precipitation of each event. From the observation of 
dried channels in the field, it is assumed that there may be ephemeral streams and ponds in the study area when it rains. As a result, the overall recharge process is rather heterogeneous. The difference in ion concentrations of these studied waters suggests that the hydraulic relationship among various sampling sites is weak.

Studies on the long-term change of seasonal snow cover in Xinjiang (e.g., Xu et al. 2009, 2010) proved that the entire catchment in the region was mainly affected by one large-scale weather system. The runoff of the Xinjiang rivers, in the past replenished by snow melt water and rainfall, is now related primarily to summer rainfall, followed by summer temperatures or the maximum snow depth in the cold season (Xu et al. 2009). These results suggest that due to climate change, snow is no longer the principal factor that contributes to the runoff increase in headstreams in Xinjiang.

\section{Explanation of water types by rainwater recharge}

The rainwater is generally of a calcium bicarbonate type, with a clear predominance of calcium over magnesium and sodium, and bicarbonate over chloride and sulfates (Meybeck 1987). The interaction of rainwater with the ground material dissolves readily weathered minerals such as calcite, releasing $\mathrm{Ca}^{2+}$, consuming $\mathrm{H}^{+}$, and increasing alkalinity and solute concentration. The achievement of this interaction will take certain time, thus being a time-dependent process. The water samples with low solute concentrations (lower TDS values and the narrow Stiff diagrams) in this study are primarily distributed in the areas with higher elevation degree (Figs. 4 and 10), where the AMP are relatively higher (Fig. 1d), indicating a rainwater recharge mechanism for these waters with little reaction time to the aquifer material. The major water type is $\mathrm{Ca}-\mathrm{HCO}_{3}$ in these areas, indicating that the water samples have contacted with calcite for certain reaction time to dissolve the calcite, but have not enough reaction time for less reactive minerals such as feldspars and micas to dissolve.

\section{Evolution of ground water with longer residence time after rainwater recharge}

Although no radiocarbon residence time can be estimated from water samples in this study on northern Xinjiang, we can estimate the evolution of ground water from geographical variation of the water chemistry and water types. Most of the samples in this study gave both higher values of $\mathrm{SO}_{4} / \mathrm{Cl}$ (Figs. $8 \mathrm{c}$ and 9) and $\mathrm{Ca} / \mathrm{Mg}$ (Fig. 8b) ratios. This result might indicate a longtime transportation and residence of natural water in the channel and aquifer, which enables the dissolution of gypsiferous fractions that are dispersed throughout the study area. Besides, the increase of solute concentrations in ground water along with the decrease of locality elevations (Figs. 10 and 11) in the study area also may be due to the longtime transportation and residence of the water in the ground and high ambient temperature.

Sodium-bearing $\left(\mathrm{Na}-\mathrm{HCO}_{3}\right.$ or $\left.\mathrm{Na}-\mathrm{NDC}\right)$ water type can form from silicate hydrolysis when longer residence time allows for the dissolution of sodium-feldspar or from the exchange of calcium for sodium during evolution of ground water after rainwater recharge. This kind of water is a transition type from $\mathrm{Ca}-\mathrm{HCO}_{3}$ to $\mathrm{Na}-\mathrm{HCO}_{3}$ or $\mathrm{Na}-\mathrm{SO}_{4}$ at a regional scale within sediments and sedimentary rock (Plummer et al. 1990; Lipfert et al. 2006) and at a small scale (500-m-wide valley) within mixed sedimentary rock (Toran and Saunders 1999), given without the influence of climate (Zhu et al. 2012a). Typical transitions along its flow path are a change from calcium bicarbonate water to sodium bicarbonate water and an increase in $\mathrm{pH}$ and dissolved solids (Toran and Saunders 1999). The $\mathrm{Ca}-\mathrm{HCO}_{3}$ waters in the studied watersheds occur primarily in the mountain areas, whereas the $\mathrm{Na}-\mathrm{HCO}_{3} / \mathrm{NDC}$ occurs close to the pediment and alluvial basin areas. As expected, the sodium bicarbonate/NDC water samples have higher $\mathrm{pH}$ and solute concentrations than the calcium bicarbonate samples. The studied watersheds in northern Xinjiang are mixed between fractured-bedrock system, sedimentary rock, and Quaternary sediments. Although there is limited knowledge of the actual flow paths under these settings, the general geochemical trends from the recharge to discharge zones show strong similarities to evolutionary trends within sedimentary aquifer systems, without point mutation occurring.

In general, we say that the calcium bicarbonate water in the studied watersheds probably represents water recharged by rainwater that has low ion concentrations and low $\mathrm{pH}$ and is dominated by calcite dissolution. The sodium bicarbonate or sodium-NDA water is the further evolved water type, with high concentrations of most chemical species and likely experienced the greatest interaction with bedrock and sediments. The geochemical evidence of greater evolution of these water types and 
their location areas with respect to likely recharge areas indicate that natural water evolution and flow-path lengths are probably important controls on the water type. Some of the features of water with high concentrations, such as sodium-sulfate and calcium-sulfate, may relate to differences in climate and other factors.

\section{Modern and past recharge}

In fluvial plains of the Zhungarer watersheds, we consider that the precipitation, which falls directly into the rivers, lakes, and reservoirs, plays a minor role in the recharge today, because the amount of precipitation is much lower than the evaporation loss taking place on the water surface. Field observations indicate that currently all rivers in these areas are recharged mainly by mountain stream water and partially by ground water. Owing to the isolated geomorphological basin structures, it is unlikely that the recharge mechanisms changed fundamentally in the past. The large range in chemical composition of water samples suggests not only the heterogeneity of the recharge conditions in the study areas but also a possible mixing with enriched waters that could come from different aquifers. However, the input from other regions (via surface runoff or ground water inflow) seems to be rather insignificant in the local water cycle. Besides, a large proportion of rain is probably added to the shallow ground water system because of rapid infiltration in the loose and sandy sediments. Field observations and interviews with local residents suggest that the water from the shallow aquifer can meet the demand of inhabitants with traditional life styles and adequate livestock in the desert environment of northern Xinjiang.

The highest TDS concentrations were observed in some lake depressions $(\mathrm{C} 5+\mathrm{C} 6+\mathrm{C} 7$ in Fig. 5 and Table 2), such as the Salimu Lake (C5 in Fig. 5 and Table 2) in the Zhungarer watershed. From the field observation, it is assumed that the Salimu Lake is mainly recharged by glacier/snow waters, because it is located in a highland depression surrounded by high mountains and there is surficial inflow but no outflow. The major ions in the lake are $\mathrm{Mg}^{2+}$ for cations and $\mathrm{SO}_{4}{ }^{2-}$ for anions. Compared with the chemistry of other lake samples, the proportions of sodium and chloride are much lower in the Salimu lake water. From a global point of view, the dominant ions in most saline lakes are $\mathrm{Na}^{+}$and $\mathrm{Cl}^{-}$(e.g., Melack 1983; Day 1993). It is reasonable to believe that the brines of these lakes were formed by long and intensive evaporation because $\mathrm{Na}^{+}$ and $\mathrm{Cl}^{-}$are often associated with evaporites. We can exclude a halite origin for the Salimu Lake. However, $\mathrm{Mg}^{2+}$ and $\mathrm{SO}_{4}{ }^{2-}$ are also often associated with evaporites. Dissolution of sulfates (such as gypsum and anhydrite) may be an important source here. The salinity of the Chinese lakes increases generally westwards, which is consistent with the trend of increasing aridity (Zhu and Yang. 2010). From this point of view, it appears that the ionic enrichment in the lakes of northern Xinjiang has been caused mainly by longtime evaporation, rather than through the quality of the recharged water.

\section{Conclusion}

The geochemistry of ground water in the large drainage system (approximately $603,000 \mathrm{~km}^{2}$ in area) of northern Xinjiang shows patterns that help to elucidate the origin and recharge of these ground waters. For comparison, two multivariate statistical techniques, HCA and PCA, were used to assess the ground water recharge and its governing factors. Q-mode HCA and R-mode PCA were combined to partition the water samples into seven major water clusters $(\mathrm{C} 1-\mathrm{C} 7)$ and three principal components (PC1-PC3: PC1 salinity, PC2 hydroclimate, PC3 contaminant). The three components PC1-PC3 explain 59.6, 16.6, and $10.9 \%$ of the total variance, respectively, and thus account for the majority of the variance. Three main hydrological areas, the recharge area, the transition area, and the discharge area, can be identified from the results of PCA and HCA. $\mathrm{C} 1+\mathrm{C} 4$ were classified as recharge area waters $\left(\mathrm{Ca}-\mathrm{HCO}_{3}\right.$ water), $\mathrm{C} 2+\mathrm{C} 3$ as transitional zone waters ( $\mathrm{Ca}-\mathrm{Mg}-\mathrm{HCO}_{3}$ $\mathrm{SO}_{4}$ water), and $\mathrm{C} 5+\mathrm{C} 6+\mathrm{C} 7$ as discharge area waters ( $\mathrm{Na}-\mathrm{SO}_{4}$ water). High $\mathrm{Na} / \mathrm{Cl}$ and $\mathrm{SO}_{4} / \mathrm{Cl}$ ratios $(\mathrm{Na} /$ $\left.\mathrm{Cl}=1.7, \mathrm{SO}_{4} / \mathrm{Cl}=6.7\right)$, together with the fact that no Cl-dominated water type occurs, are indicative of strong water-rock interaction. Based on the Q-mode PCA scores, three groups of geochemical processes influencing recharge regimes were identified: geogenic (i.e., caused by natural geochemical processes), geomorphoclimatic (caused by topography and climate), and anthropogenic (caused by ground water contamination). The $\mathrm{Ca}-\mathrm{HCO}_{3}$ water is rainwater recharged with low solute concentration, probably due to little reaction time to the ground material. The Na-sulfate waters are the most chemically evolved of the water types, indicating longer flow paths. Ca-Mg-sulfate 
waters are less evolved than the Na-sulfate waters, but more so than the $\mathrm{Ca}-\mathrm{HCO}_{3}$ waters and likely derive considerable recharge from the $\mathrm{Ca}-\mathrm{HCO}_{3}$ area based on their downgradient locations. The highest solute concentrations were observed in waters from lake depressions $(\mathrm{C} 5+\mathrm{C} 6+\mathrm{C} 7)$. It appears that the ionic enrichment in these waters is caused mainly by longtime evaporation, rather than through the quality of the recharged water. The central parts of northern Xinjiang watersheds are at particular risk of secondary salinity, as there is no salt removal mechanism. The study demonstrates the general usefulness of ground water chemistry differentiation for supporting identification of ground water recharge and evolution patterns.

Acknowledgments This work was financially supported by the National Natural Science Foundation of China (Grant no.: 41371060) and the Kezhen Young Talent Project of the IGSNRR-CAS (Grant no.: 2013RC101). The author is very grateful to Profs. Patrick Rioual, Xiaoguang Qin, Jingjie Yu, and Xiaoping Yang for their generous help in the research work. Sincere thanks are extended also to the editor Prof. Yu-Pin Lin and four anonymous reviewers for their incisive reviews of the manuscript.

\section{References}

Adams, S., Titus, R., Pietersen, K., Tredoux, G., \& Harris, C. (2001). Hydrochemical characteristics of aquifers near Sutherland in the Western Karoo, South Africa. Journal of Hydrology, 241, 91-103.

Aiuppa, A., Bellomo, S., Brusca, L., D’Alessandro, W., \& Federico, C. (2003). Natural and anthropogenic factors affecting groundwater quality of an active volcano (Mt. Etna, Italy). Applied Geochemistry, 18, 863-882.

Arnell, N. W. (1999). The effect of climate change on hydrological regimes in Europe: a continental perspective. Global Environmental Change, 9, 5-23.

Barnett, T. P., Adam, J. C., \& Lettenmaier, D. P. (2005). Potential impacts of a warming climate on water availability in snowdominated regions. Nature, 438, 303-309.

Cartwright, I., \& Weaver, T. R. (2005). Hydrogeochemistry of the Goulburn Valley region of the Murray Basin, Australia: implications for flow paths and resources vulnerability. Hydrogeology Journal, 13, 752-770.

Cloutier, V., Lefebvre, R., Therrien, R., \& Savard, M. M. (2008). Multivariate statistical analysis of geochemical data as indicative of the hydrogeochemical evolution of groundwater in a sedimentary rock aquifer system. Journal of Hydrology, 353, 294-313.

Cramer, V., \& Hobbs, R. J. (2002). Ecological consequences of altered hydrological regimes in fragmented ecosystems in southern Australia: impacts and possible management responses. Austral Ecology, 27, 546-564.
Davis, J. C. (1986). Statistics and data analysis in geology. New York: John Wiley \& Sons Inc.

Day, J. A. (1993). The major ion chemistry of some southern African saline systems. Hydrobiologia, 267, 37-59.

Domros, M., \& Peng, G. (1988). The climate of China. Berlin: Springer.

Dragon, K. (2006). Application of factor analysis to study contamination of a semi-confined aquifer (Wielkopolska Buried Valley aquifer, Poland). Journal of Hydrology, 331, 272-279.

Dragon, K., \& Gorski, J. (2009). Identification of hydrogeochemical zones in postglacial buried valley aquifer (Wielkopolska Buried Valley aquifer, Poland). Environmental Earth Sciences, 58, 859-866.

Dragon, K., \& Gorski, J. (2015). Identification of groundwater chemistry origins in a regional aquifer system (Wielkopolska region, Poland). Environmental Earth Sciences, 73, 21532167.

Fontes, J. C. h., Louvat, D., Michelot, J. L., \& Soreau, S. (1988). Isotopic content of aqueous sulphate, indicators of the origin of mineralization in crystalline rock groundwaters. In Proceedings IAH symposium on the hydrogeology and safety of radioactive and industrial hazardous waste disposal (pp. 325-341). Doc. BRGM 160, OrleAans.

Garg, R. K., Rao, R. J., Uchchariya, D., Shukla, G., \& Saksena, D. N. (2010). Seasonal variations in water quality and major threats to Ramsagar reservoir, India. African Journal of Environmental Science and Technology, 4(2), 61-76.

George, R. J., McFarlane, D. J., \& Nulsen, R. A. (1997). Salinity threatens the viability of agriculture and ecosystems in Western Australia. Hydrogeology Journal, 5, 6-21.

Guler, C., \& Thyne, G. D. (2004). Hydrologic and geologic factors controlling surface and groundwater chemistry in Indian Wells-Owens valley area, southeastern California, USA. Journal of Hydrology, 285, 177-198.

Guler, C., Thyne, G. D., McCray, J. E., \& Turner, A. K. (2002). Evaluation of graphical and multivariate statistical methods for classification of water chemistry data. Hydrogeology Journal, 10, 455-474.

Hagg, W., Braun, L. N., Kuhn, M., \& Nesgaard, T. L. (2007). Modeling of hydrological response to climate change in glacierized Central Asian catchments. Journal of Hydrology, 332, 40-53.

Han, D., Liang, X., Jin, M., Currell, J. M., Han, Y., \& Song, X. (2009). Hydrogeochemical indicators of groundwater flow systems in the Yangwu River alluvial fan, Xinzhou Basin, Shanxi, China. Environmental Management, 44, 243-255.

Helstrup, T., Jorgensen, N. O., \& Banoeng-Yakubo, B. (2007). Investigation of hydrochemical characteristics of groundwater from Cretaceous-Eocene limestone aquifers in southern Ghana and Togo using hierarchical cluster analysis. Hydrogeology Journal, 15, 977-989.

Huang, G., Sun, J., Zhang, Y., Chen, Z., \& Liu, F. (2013). Impact of anthropogenic and natural processes on the evolution of groundwater chemistry in a rapidly urbanized coastal area, South China. Science of the Total Environment, 463-464, 209-221.

Huh, Y., Tsoi, M. Y., Zaitsev, A., \& Edmond, M. (1998a). The fluvial geochemistry of the rivers of eastern Siberia: I. Tributaries of the Lena river draining the sedimentary platform of the Siberian craton. Geochimica et Cosmochimica Acta, 62, 1657-1676. 
Huh, Y., Babich, D., Zaitsev, A., \& Edmond, J. M. (1998b). The fluvial geochemistry of the rivers of eastern Siberia: II. Tributaries of the Lena, Omoloy, Yana, Indigirka, Kolyma, and Anadyr draining the collisional/accretionary zone of the Verkhoyansk and Cherskiy ranges. Geochimica et Cosmochimica Acta, 62, 2053-2075.

Jahn, B. M., Wu, F., \& Chen, B. (2000). Granitoids of the central Asian orogenic belt and continental growth in the Phanerozoic. Transactions of the Royal Society of Edinburgh: Earth Sciences, 91, 181-193.

Jolly, I. D., McEwan, K. L., \& Holland, K. L. (2008). A review of groundwater-surface water interactions in arid/semi-arid wetlands and the consequences of salinity for wetland ecology. Ecohydrology, 1, 43-58.

Kimbadi, S., Vandelannoote, A., Deelstra, H., Mbemba, M., \& Ollevier, F. (1999). Chemical composition of the small rivers of the north-western part of Lake Tanganyika. Hydrobiologia, 407, 75-80.

Lipfert, G., Reeve, A. S., Sidle, W. C., \& Marvinney, R. (2006). Geochemical patterns of arsenic-enriched ground water in fractured, crystalline bedrock, Northport, Maine, USA. Applied Geochemistry, 21, 528-545.

Ma, L. (2002). Geological atlas of China. Beijing: Geological Press (in Chinese).

Maxey, G. B. (1968). Hydrogeology of desert basins. Ground Water, 6, 10-22.

Maya, A. L., \& Loucks, M. D. (1995). Solute and isotopic geochemistry and groundwater flow in the Central Wasatch Range, Utah. Hydrological Journal, 172, 31-59.

Melack, J. M. (1983). Large, deep salt lakes: a comparative limnological analysis. Hydrobiologia, 105, 223-230.

Menzel, L., \& Burger, G. (2002). Climate change scenarios and runoff response in the Mulde catchment (southern Elbe, Germany). Journal of Hydrology, 267, 53-64.

Meybeck, M. (1987). Global chemical weathering of surficial rocks estimated from river dissolved loads. American Journal of Science, 287, 401-428.

Meyer, J. L., McDowell, W. H., Bott, T. L., Elwood, J., Ishizaki, C., Melack, J. M., Peckarsky, B., Peterson, B., \& Rublee, P. (1988). Elemental dynamics in streams. Journal of the North American Benthological Society, 7, 410-432.

Monjerezi, M., Vogt, R. D., Aagaard, P., \& Saka, J. D. K. (2011). Hydro-geochemical processes in an area with saline groundwater in lower Shire River valley, Malawi: an integrated application of hierarchical cluster and principal component analyses. Applied Geochemistry, 26, 1399-1413.

Noh, H., Huh, Y., Qin, J., \& Ellis, A. (2009). Chemical weathering in the three rivers region of Eastern Tibet. Geochimica et Cosmochimica Acta, 73, 1857-1877.

Papatheodorou, G., Lambrakis, N., \& Panagopoulos, G. (2007). Application of multivariate statistical procedures to the hydrochemical study of a coastal aquifer: an example from Crete, Greece. Hydrological Processes, 21, 1482-1495.

Pawellek, F., Frauenstein, F., \& Veizer, J. (2002). Hydrochemistry and isotope geochemistry of the upper Danube River. Geochimica et Cosmochimica Acta, 66, 3839-3854.

Pilla, G., Sacchi, E., Zuppi, G., Braga, G., \& Ciancetti, G. (2006). Hydrochemistry and isotope geochemistry as tools for groundwater hydrodynamic investigation in multilayer aquifers: a case study from Lomellina, Po plain, South-Western Lombardy, Italy. Hydrogeology Journal, 14, 795-808.

Piper, A. M. (1944). A graphic procedure in the geochemical interpretation of water-analyses. Transactions of the American Geophysical Union, 25, 914-923.

Plummer, L. N., Busby, J. F., Lee, R. W., \& Hanshaw, B. B. (1990). Geochemical modelling of the Madison aquifer in parts of Montana, Wyoming, and South Dakota. Water Resources Research, 26, 1981-2014.

Rosen, M., \& Jones, S. (1998). Controls on the chemical composition of groundwater from alluvial aquifers in the Wanaka and Wakatipu basins, central Otago, New Zealand. Hydrogeology Journal, 6, 264-268.

Stadler, S., Osenbrück, K., Suckow, A. O., Himmelsbach, T., \& Hötzl, H. (2010). Groundwater flow regime, recharge and regional-scale solute transport in the semi-arid Kalahari of Botswana derived from isotope hydrology and hydrochemistry. Journal of Hydrology, 388, 291-303.

Stetzenbach, K. J., Hodge, V. F., Guo, C., Farnham, I. M., \& Johannesson, K. H. (2001). Geochemical and statistical evidence of deep carbonate groundwater within overlying volcanic rock aquifers/aquitards of southern Neveda, USA. Journal of Hydrology, 243, 254-271.

Stiff, H. A. (1951). The interpretation of chemical water analysis by means of patterns. Journal of Petroleum Technology, 3, $15-16$.

Sun, J., Ye, J., Wu, W., Ni, X., Bi, S., Zhang, Z., Liu, W., \& Meng, J. (2010). Late Oligocene-Miocene mid-latitude aridification and wind patterns in the Asian interior. Geology, 38, 515518.

Toran, L. E., \& Saunders, J. A. (1999). Modeling alternative paths of chemical evolution of Na-HCO3-type ground water near Oak Ridge, Tennessee, USA. Hydrological Journal, 7, 355364.

UNEP (1992). World atlas of desertification. London: United Nations Environment Programme.

Usunoff, E. J., \& Guzman-Guzman, A. (1989). Multivariate analysis in hydrochemistry: an example of the use of factor and correspondence analyses. Ground Water, 27, 27-34.

Van den Brink, C., Frapporti, G., Griffioen, J., \& Jan Zaadnoordijk, W. (2007). Statistical analysis of anthropogenic versus geochemical-controlled differences in groundwater composition in The Netherlands. Journal of Hydrology, 336, 470-480.

Wang, S. W., Liu, C. W., \& Jang, C. S. (2007). Factors responsible for high arsenic concentrations in two groundwater catchments in Taiwan. Applied Geochemistry, 22, 460-476.

Wetzel, R. G., \& Likens, G. E. (2000). Limnological analyses (3rd ed.). Springer: New York.

WHO (2008). Guidelines for drinking water quality. Geneva: World Health Organization.

XETCAS (Xinjiang Expedition Team of the Chinese Academy of Sciences), IGCAS (Institute of Geography of the Chinese Academy of Sciences), \& DGBNU (Department of Geography of Beijing Normal University) (1978). Geomorphology in Xinjiang. Beijing: Science Press (in Chinese).

Xu, C. C., Chen, Y., Hamid, Y., Tashpolat, T., Chen, Y., Ge, H., \& Li, W. (2009). Long-term change of seasonal snow cover and its effects on river runoff in the Tarim River basin, northwestern China. Hydrological Processes, 23, 2045-2055. 
Xu, C. C., Chen, Y., Yang, Y., Hao, X., \& Shen, Y. (2010). Hydrology and water resources variation and its response to regional climate change in Xinjiang. Journal of Geographical Sciences, 20, 599-612.

Yidana, S. M. (2010). Groundwater classification using multivariate statistical methods: southern Ghana. Journal of African Earth Sciences, 57, 455-469.

Zghibi, A., Merzougui, A., Zouhri, L., \& Tarhouni, J. (2014). Understanding groundwater chemistry using multivariate statistics techniques to the study of contamination in the Korba unconfined aquifer system of Cap-Bon (North-east of Tunisia). Journal of African Earth Sciences, 89, 1-15.

Zhu, B., \& Yang, X. (2007). The ion chemistry of surface and ground waters in the Taklimakan Desert of Tarim Basin, western China. Chinese Science Bulletin, 52, 2123-2129.

Zhu, B., \& Yang, X. (2010). The origin and distribution of soluble salts in the sand seas of northern China. Geomorphology, 123, 232-242.

Zhu, G. F., Li, Z. Z., Su, Y. H., Ma, J. Z., \& Zhang, Y. Y. (2007). Hydrogeochemical and isotope evidence of groundwater evolution and recharge in Minqin Basin, Northwest China. Journal of Hydrology, 333, 239-251.

Zhu, B., Yang, X., Rioual, P., Qin, X., Liu, Z., Xiong, H., \& Yu, J. J. (2011). Hydrogeochemistry of three watersheds (the Erlqis,
Zhungarer and Yili) in northern Xinjiang, NW China. Applied Geochemistry, 26, 1535-1548.

Zhu, B., Yu, J., Qin, X., Rioual, P., \& Xiong, H. (2012a). Climatic and geological factors contributing to the natural water chemistry in an arid environment from watersheds in northern Xinjiang, China. Geomorphology, 153-154, 102-114.

Zhu, B., Yang, X., Liu, Z., Rioual, P., Li, C., \& Xiong, H. (2012b). Geochemical compositions of soluble salts in aeolian sands from the Taklamakan and Badanjilin deserts in northern China, and their influencing factors and environmental implications. Environmental Earth Sciences, 66, 337-353.

Zhu, B., Yu, J., Qin, X., Rioual, P., Liu, Z., Zhang, Y., Jiang, F., Mu, Y., Li, H., Ren, X., \& Xiong, H. (2013a). The significance of mid-latitude rivers for weathering rates and chemical fluxes: evidence from northern Xinjiang rivers. Journal of Hydrology, 486, $151-174$

Zhu, B., Yu, J., Qin, X., Rioual, P., Zhang, Y., Liu, Z., Mu, Y., Li, H., Ren, X., \& Xiong, H. (2013b). Identification of rock weathering and environmental control in arid catchments (northern Xinjiang) of Central Asia. Journal of Asian Earth Sciences, 66, 277-294. 